\title{
Intestinal gene expression in pigs: effects of reduced feed intake during weaning and potential impact of dietary components
}

\author{
Eva Bauer ${ }^{1,2 *}$, Barbara U. Metzler-Zebeli ${ }^{3}$, Martin W. A. Verstegen ${ }^{2}$ and Rainer Mosenthin ${ }^{1}$ \\ ${ }^{1}$ Institute of Animal Nutrition, University of Hohenheim, 70593 Stuttgart, Germany \\ ${ }^{2}$ Animal Nutrition Group, Wageningen University, 6709 Wageningen, The Netherlands \\ ${ }^{3}$ Leibniz-Institute for Farm Animal Biology, Research Unit Nutritional Physiology 'Oskar Kellner', 18196 Dummerstorf, \\ Germany
}

\section{Abstract}

The weaning transition is characterised by morphological, histological and microbial changes, often leading to weaning-associated disorders. These intestinal changes can partly be ascribed to the lack of luminal nutrition arising from the reduced feed intake common in pigs after weaning. It is increasingly becoming clear that changes in the supply with enteral nutrients may have major impacts on intestinal gene expression. Furthermore, the major dietary constituents, i.e. carbohydrates, fatty acids and amino acids, participate in the regulation of intestinal gene expression. However, nutrients may also escape digestion by mammalian enzymes in the upper gastrointestinal tract. These nutrients can be used by the microflora, resulting in the production of bacterial metabolites, for example, SCFA, which may affect intestinal gene expression indirectly. The present review provides an insight on possible effects of reduced feed intake on intestinal gene expression, as it may occur post-weaning. Detailed knowledge on effects of reduced feed intake on intestinal gene expression may help to understand weaning-associated intestinal dysfunctions and diseases. Examples are given of intestinal genes which may be altered in their expression due to supply with specific nutrients. In that way, gene expression could be modulated by dietary means, thereby acting as a potential therapeutic tool. This could be achieved, for example, by influencing genes coding for digestive or absorptive proteins, thus optimising digestive function and metabolism, but also with regard to immune response, or by influencing proliferative processes, thereby enhancing mucosal repair. This would be of special interest when designing a diet to overcome weaning-associated problems.

Key words: Intestinal gene expression: Weaning: Feed intake: Pigs

\section{Introduction}

For piglets, the weaning transition from milk to a solid diet is characterised by a multitude of changes in the intestinal morphology and function, often accompanied by weaningassociated disorders ${ }^{(1)}$. The various intestinal changes associated with weaning can, at least in part, be ascribed to the distinct lack of luminal nutrition arising as a consequence of reduced feed intake immediately after weaning ${ }^{(2)}$. Furthermore, several studies have shown that fasting or reduced feed intake may influence intestinal gene expression; for example, changes in intestinal gene expression have been reported for brush-border enzymes and nutrient transporters ${ }^{(3,4)}$, and growth factors ${ }^{(5,6)}$. Although coordinated alterations of intestinal gene expression were observed in piglets in response to weaning ${ }^{(7)}$, it is not always clear whether these changes are due to the weaning process per se or more related to associated reductions in feed intake.

Furthermore, specific micro- and macronutrients can have profound influence on intestinal gene expression, and, accordingly, on metabolism and on homeostasis ${ }^{(8,9)}$. The main agents through which nutrients influence gene expression are the transcription factors, which bind to specific DNA sequences of genes, thereby activating or inhibiting their transcription ${ }^{(10)}$ and translating nutritional stimuli into changes in gene expression ${ }^{(11)}$. For example, a group of transcription factors, referred to as PPAR, are sensitive to dietary fatty acids $^{(12)}$, and some of them (PPAR- $\gamma$ ) are involved in the regulation of a number of inflammatory genes ${ }^{(13,14)}$, thereby leading to attenuation of inflammation. Thus, it seems to be possible that specific dietary components may beneficially influence response

\footnotetext{
Abbreviations: CLA, conjugated linoleic acid; GIT, gastrointestinal tract; GLP, glucagon-like peptide; HDAC, histone deacetylase; IEL, intra-epithelial lymphocyte; IFN, interferon; IGF, insulin-like growth factor; IGFBP, insulin-like growth factor-binding protein; KGF, keratinocyte growth factor; LPS, lipopolysaccharide; MCT, medium-chain TAG; Pept1, peptide transporter-1; PGDP, proglucagon-derived peptide; sIgA, secretory IgA; SGLT1, Na-coupled glucose co-transporter-1; TGF, transforming growth factor; TPN, total parenteral nutrition.
} 
variables related, for example, to immune function and inflammation. In that way, diet could help to overcome problems associated to times of multiple stressors, as they occur, for example, during weaning. The present review includes two objectives. First, it aims to provide an insight on possible effects of reduced feed intake on intestinal gene expression, as it may occur during the weaning transition. This may help to understand intestinal dysfunctions and diseases related to the weaning period. Data from studies focusing on the effect of fasting or total parental nutrition (TPN) have been included, as effects of experimental fasting seem to correspond to the effects of immediate post-weaning anorexia ${ }^{(2,15)}$. Second, it is hypothesised under which conditions intestinal gene expression could be modulated by dietary means, thereby acting as a potential therapeutic tool. Therefore, examples are given of intestinal genes which may be altered in their expression as a consequence of supply with specific dietary nutrients, including carbohydrates, fats and proteins/ amino acids. Reference is also made to studies investigating the effect of microbial fermentation metabolites on intestinal gene expression, as some of them, for example, SCFA $^{(16,17)}$, have been shown to affect gene expression ${ }^{(18)}$. As manipulation of the diet may be an appropriate way of changing the composition and activity of the gastrointestinal microflora ${ }^{(19,20)}$, this would open further perspectives to indirectly affect intestinal gene expression. The present review includes mainly data from pigs and rodents, but, if applicable, also from other species.

\section{The weaning transition: a brief summary}

For piglets, weaning involves complex psychological, social, environmental and dietary stresses that interfere with intestinal development and adaptation (Table 1). The immediate effect of weaning is a dramatic reduction in feed (energy) intake for up to 2 or $3 \mathrm{~d}^{(1)}$ leading to undernutrition and a transient growth $\operatorname{check}^{(21)}$. This temporary weaning anorexia results in alterations of intestinal integrity and appears to be one of the major aetiological factors in gut-associated disorders ${ }^{(15,22,23)}$. Intestinal alterations often seen in piglets post-weaning include changes in villus-crypt architecture and in activities of many brushborder digestive enzymes. For example, marked villus atrophy ( -45 to $-70 \%$ of pre-weaning values), particularly in the proximal small intestine, has been repeatedly reported during the degenerative phase ${ }^{(15,23)}$. Also, a reduction of lactase activity followed by increased maltase and sucrase activities immediately post-weaning have been consistently reported and may reflect maturation of intestinal function in relation to the weaning diet ${ }^{(15)}$. These changes are thought to temporarily decrease the digestive and absorptive capacity of the small intestine. Furthermore, the transient alteration of intestinal integrity is characterised by increased mucosal permeability, and disturbed absorptive-secretory balance ${ }^{(24)}$, probably also related to the weaning-associated fasting period imposed on piglets ${ }^{(25,26)}$. In addition, a stimulation of pro-inflammatory cytokine gene expression in piglets post-weaning has also been reported ${ }^{(27)}$. The pro-inflammatory cytokines IL-1 $\beta$, IL-6 and TNF- $\alpha$ represent early non-specific mediators of inflammation, and are known to affect intestinal epithelial permeability and transport ${ }^{(1,28)}$. Furthermore, increased $\mathrm{T}$ cell numbers and increased local expression of the matrix metalloproteinase stromelysin in the small intestine have been measured during post-weaning anorexia in piglets, and may contribute to intestinal inflammation ${ }^{(2)}$. In addition, the transition from milk to a solid diet leads to dramatic changes in the composition of the microbial population of the gastrointestinal tract (GIT) during the 7-14d after weaning ${ }^{(29)}$. According to Ewing \& Cole ${ }^{(30)}$, numbers of lactobacilli and other beneficial bacteria decrease in times of stress, as do their beneficial effects. This allows potential pathogens such as coliforms to increase. Franklin et $a l^{(31)}$ found that lactobacilli populations in different GIT sections (jejunum, ileum, caecum) declined to lower levels in early-weaned pigs (17d), compared with pigs weaned at $24 \mathrm{~d}$. Accordingly, Janczyk et $a l{ }^{(32)}$ found dramatic changes in the diversity of lactobacilli populations in the ileum around weaning. According to Konstantinov et al. ${ }^{(33)}$, two Lactobacillus species dominate in ileal samples of neonatal and unweaned piglets, but following weaning, these two lactobacilli significantly declined in numbers. Such weaning-associated changes

Table 1. Weaning transition in young pigs (adapted from Lallès et al. ${ }^{(1)}$ )

\begin{tabular}{ll}
\hline Immature animal for & Behaviour \\
& Intestinal function (secretions, motility, digestion, absorption, defence, etc.) \\
& Immune system \\
Stress & Psychological: separation from mother; mixing with other litters; new environment \\
& Dietary: withdrawal of milk; access to dry feed \\
Alterations in intestinal & Morphology: villous atrophy followed by crypt hyperplasia \\
architecture and function & Reduced activities of intestinal digestive enzymes \\
& Disturbed intestinal absorption, secretion and permeability \\
Main risk factors & Disturbed microbial ecology and associated enteric pathogens (for example, Escherichia coli, rotavirus, etc.) \\
& Dietary: low feed intake; antinutritional factors; diets with high component complexity and low digestibility; \\
& high protein level (+high buffering capacity) \\
& Rearing: large litter size and low weaning weight; high density of piglets post-weaning; low level of hygiene; \\
& inadapted environment (low temperature, low air quality, etc.)
\end{tabular}


in the intestinal microbiota can, in turn, also influence immune development ${ }^{(34)}$. However, the molecular mechanisms underlying weaning anorexia and refeeding are not well established in piglets ${ }^{(35)}$. Recent studies which used microarray techniques have shown that weaning in piglets coincides with marked alterations in the expression of various intestinal genes, related to nutrient metabolism and/or cell proliferation and/or immune function ${ }^{(7,36)}$. Such information would be relevant for improving the understanding of post-weaning gut disorders ${ }^{(35)}$.

\section{Changes in intestinal gene expression due to reduced feed intake \\ Digestive function and nutrient metabolism}

Several studies with rodents have investigated effects of changes in the nutritional status on intestinal gene expression, for example, of intestinal nutrient transporters. For example, short-term starvation in rats leads to a substantial increase in mRNA levels of the monosaccharide carrier by which fructose is absorbed (GLUT5) ${ }^{(37)}$. Other nutrient transporters that are sensitive to alterations of the nutritional status are the oligopeptide transporters, such as the $\mathrm{H}^{+}$-dependent peptide transporter-1 (Pept1), which is responsible for absorption of the products of protein digestion from the intestinal lumen into the epithelial cell such as dipeptides and tripeptides ${ }^{(38)}$. It is accepted that Pept1 gene regulation is, amongst other factors, regulated by the diet ${ }^{(39)}$. Short-term starvation over a period of 1 or $4 \mathrm{~d}$ in rats increases dipeptide absorption rates, paralleled by increases in Pept1 protein and mRNA levels ${ }^{(40,41)}$. Similarly, increases in Pept1 mRNA levels were observed for rats which received $7 \mathrm{~d}^{\mathrm{TPN}}{ }^{(42)}$. This was also observed after $10 \mathrm{~d}$ of TPN, and an increased Pept1 protein density was noted $^{(3)}$. Consequently, fasting, both during shortterm or prolonged periods, increases the Pept1 mRNA level, resulting in an increase in the population of the transporter in the brush-border membrane of the intestinal mucosa $^{(43)}$. Increased expression and activity of Pept1 during feed deprivation or restriction may serve as a mechanism to compensate for a reduced mucosal surface $\operatorname{area}^{(39)}$. According to Barbot et al. ${ }^{(44)}$, the physiological significance of increased expression is to counterbalance the shortening of the absorptive surface during starvation. The latter can be even more important when there is an infection. For example, an enhanced level of Pept1 mRNA was found in suckling rats during acute cryptosporidiosis. This is an infection with Cryptosporidium parvum which frequently results in diarrhoea ${ }^{(44)}$. The authors suggested that this transcriptional up-regulation plays an important role in the adaptation to malnutrition associated with cryptospiridiosis. Although the study of Barbot et al. ${ }^{(44)}$ was performed with rats, one could also imagine a similar mechanism for pigs, to overcome malnutrition associated with diarrhoea. A mechanism for this induction of intestinal Pept1 during fasting was proposed by Shimakura et al. ${ }^{(45)}$. They demonstrated in rats that the fasting-induced up-regulation of Pept1 expression is mediated via PPAR- $\alpha$, a member of a family of ligandactivated nuclear receptors. The nuclear receptors are one of the largest groups of transcription factors, and are the most important group of nutrient sensors ${ }^{(10,46,47)}$. PPAR- $\alpha$ is an important mediator of the hepatic response to fasting, and is believed to be a major regulator of lipid and glucose metabolism, allowing adaptation to the prevailing nutritional environment ${ }^{(48-50)}$. Shimakura et al. ${ }^{(45)}$ hypothesised that increased Pept 1 minimises the loss of $\mathrm{N}$ by efficient absorption of small-intestinal peptides derived from sloughing cells or secreted hormones. Furthermore, such an induction of Pept1 expression might be a preparation for adaptation when food is given again after fasting.

Also, the gene expression of intestinal transporters and phase I/II metabolic enzymes, which are required for adequate metabolism and excretion of various endogenous molecules, nutrients and xenobiotics, is affected by fasting ${ }^{(51,52)}$. According to a study of Van den Bosch et al. ${ }^{(52)}$ in the murine small intestine, $24 \mathrm{~h}$ of fasting resulted in the up-regulation of genes, for example, involved in the transport of energy-yielding molecules during glycogenolysis and during mitochondrial and peroxisomal oxidation of fatty acids. As some of the transporters and phase I and II genes are regulated in dependency of PPAR- $\alpha$, it appears that the absorptive and detoxification capacity of the small intestine is altered during fasting, and PPAR- $\alpha$ mediates a part of these alterations ${ }^{(52)}$.

Le Huërou-Luron et al. ${ }^{(53)}$ studied in piglets small-intestinal changes due to weaning and found that a post-weaning increase of maltase activity paralleled that of maltase mRNA. In their study, maltase mRNA abundance and activity were $2 \cdot 3$-fold higher in $25 \mathrm{~d}$ weaned control than in $18 \mathrm{~d}$-suckled piglets. Marion et al. ${ }^{(54)}$ investigated the effect of feed intake level after weaning on the activity of several brush-border enzymes and mRNA levels in earlyweaned piglets (aged $7 \mathrm{~d}$ ). In their study, however, only maltase showed weaning-induced increases in activity, which were closely correlated with corresponding mRNA levels. This suggests a mainly transcriptional regulation of maltase in response to weaning. However, changes in specific activities of brush-border enzymes during weaning may also reflect indirect effects resulting from a lower feed intake. Indeed, the most striking consequence of postweaning anorexia is a rapid mucosal atrophy of the small intestine, associated with a reduction of villous height and increases in crypt depth which are generally associated with reductions in the specific activities of the brush-border enzymes lactase and sucrase ${ }^{(15,55)}$. Alterations of intestinal integrity, however, were also observed in underfed piglets and piglets receiving TPN, when compared with their counterparts being fed ad libitum or receiving enteral nutrition, independently of the weaning process ${ }^{(26,56)}$ 
Mazurais et $a l .{ }^{(35)}$ investigated the impact of fasting and refeeding on the piglet's jejunal transcriptome during the weaning period. In their study, 21-d-old sow-reared piglets were fasted for $2 \mathrm{~d}$ before slaughtering at the age of $23 \mathrm{~d}$. Porcine arrays associated with real-time PCR were used to assess global gene expression changes in the jejunum of piglets at weaning. In this study, some genes associated with carbohydrate and lipid metabolism (6-phosphofructokinase, pyruvate kinase, triosephosphate isomerase, apoAIV) were down-expressed in fasted and refed animals, while other genes involved in carbohydrate metabolism, for example, a member of carbonyl-reducing enzymes (short-chain dehydrogenase/reductase (SDR) family member 4$)^{(57)}$, were up-expressed in fasted piglets. The authors concluded from their study a major impact of weaning on the jejunal transcriptome. Although a direct correlation between transcriptomic regulation and functional impact is not always clearly to establish, more information on the underlying mechanisms of weaningassociated anorexia and subsequent refeeding would be needed for better understanding of weaning-associated gut disorders. Also, Wang et al. ${ }^{(7)}$ studied a wide range of genes by using microarray technology. They showed that early weaning in piglets coincides with a modulation of small-intestinal expression of several genes. In this study, feed intake was reduced by $36 \%$ in weaned piglets as compared with suckling piglets. Reduced expression was shown in pigs aged $28 \mathrm{~d}$ weaned at age $21 \mathrm{~d}$ in comparison with age-matched suckling piglets, amongst others, for genes encoding for proteins related to protein and peptide degradation (for example, aminopeptidase A, cathepsin F), lipid metabolism (for example, acyl-CoA dehydrogenase, carnitine transporter 2) and intestinal transport (for example, apoA-IV precursor, fatty acidbinding protein, sodium- and chloride-dependent creatine transporter I). Down-regulation of these genes is expected to reduce intestinal transport and utilisation of dietary nutrients (particularly lipids and proteins). Other genes of lipid metabolism (for example, hydroxymethylglutarylCoA synthase, squalene epoxidase), but also of carbohydrate metabolism (galactoside $2-\alpha$-L-fucosyltransferase), showed enhanced expression. The authors concluded that early weaning would result in a decreased expression of genes related to nutrient utilisation.

\section{Immune function}

Wildhaber et al. ${ }^{(58)}$ investigated the effect of completely reduced enteral nutrition on the function of intra-epithelial lymphocytes (IEL), as measured by IEL cytokine mRNA expression in mice. In this study, TPN-mice showed a decline in IL-2 and IL-10 expression, while IL-4, IL-6, interferon (IFN)- $\gamma$, transforming growth factor (TGF)- $\beta 1$ and TNF- $\alpha$ were increased, as compared with mice receiving oral feeding, or receiving TPN plus oral feeding. This suggests that the lack of enteral nutrition is responsible for changes in intestinal immune function caused by TPN, and not the administration of the TPN solution itself. Alterations of IEL cytokine mRNA expression (for example, an increased IFN- $\gamma$ mRNA expression) have also been shown by Kiristioglu \& Teitelbaum ${ }^{(59)}$ in mice receiving TPN. Changes in the expression of IEL-derived cytokines, particularly an up-regulation of IFN- $\gamma$ expression, may be associated with a loss of epithelial barrier function in mice ${ }^{(60)}$. This may contribute to problems often associated with TPN, such as an increased rate of bacterial translocation ${ }^{(61)}$. For the young animal, this would provide a link between weaning-associated anorexia, i.e. lack of luminal nutrition, and an enhanced susceptibility to intestinal infections observed during this period. A modified epithelial barrier function has also been observed in piglets resulting from weaning-associated anorexia, and might allow the passage of pathogens possibly leading to diarrhoea ${ }^{(1,24)}$. Additionally, Fukatsu et al. ${ }^{(62)}$ showed a decrease in IL- 4 and IL-10 mRNA expression in lamina propria cells of mice receiving TPN compared with mice fed normal chow. These immunoregulatory cytokines are known as IgA-stimulating cytokines. As IgA is a critical component in mucosal immunity and barrier integrity, a decrease in expression of these cytokines would explain impaired mucosal immunity associated with the lack of enteral feeding ${ }^{(62,63)}$.

The process of weaning is associated with large differences in the number of genes expressed in the jejunal mucosa of piglets directly after weaning (aged 4 weeks) in comparison with older pigs (aged 12 weeks). The most notable contrast was the high number of immuneassociated genes expressed in 4-week-old animals ${ }^{(36)}$. Furthermore, Wang et al. ${ }^{(7)}$ observed that early weaning modulated the expression of several genes in the small intestine of piglets (as compared with suckling piglets), mostly with an increased expression of genes that promote oxidative defence and immune activation. For example, enhanced expression was observed for genes responsible for immune function, for example, Ig $\alpha$ chain $\mathrm{C}$, Igк chain $\mathrm{C}, \operatorname{Ig} \lambda$ chain and $\mathrm{IgJ}$ chain. These belong to polypeptide chains composing an antibody molecule. Also enhanced expression was shown for polymeric Ig receptor precursor and for lysozyme. The polymeric Ig receptor is a cell surface receptor of mucosal epithelial cells that mediates the transport of IgA and IgM through the epithelial cells into the intestinal lumen, where they function as inhibitors of bacterial/viral adherence and penetration of the underlying epithelium ${ }^{(64)}$, while lysozyme is an antimicrobial protein ${ }^{(65)}$. An increased expression of glutathione transferase $\omega-1$ could also be seen, suggesting the presence of oxidative stress in the small intestine of weaned piglets ${ }^{(7,66)}$. Indeed, intestinal oxidative stress has been associated with the initiation and propagation of intestinal pathologies, for example, ischaemic-reperfusion disorders ${ }^{(67,68)}$ for which intestinal lesions have been shown for newborn piglets similar to those seen in human newborns with 
necrotising enterocolitis ${ }^{(69,70)}$. Furthermore, in piglets the pattern of pro-inflammatory cytokine gene expression in the intestine changes throughout weaning (weaned age $28 \mathrm{~d}$ ), with an up-regulation of IL- $1 \beta$, IL- 6 and TNF- $\alpha$ mRNA during the first $2 \mathrm{~d}$ post-weaning. After $2 \mathrm{~d}$ post-weaning, the mRNA level of these cytokines returned to pre-weaning levels, with the exception of TNF- $\alpha$ mRNA level in the distal small intestine, which remained high ${ }^{(27)}$. The cytokine IL-1 $\beta$ can be up-regulated in response to a wide range of specific and non-specific stimuli. In the study of Pié et al. ${ }^{(27)}$, IL-1 $\beta$ expression increased in all segments investigated, suggesting that its up-regulation seems to be more related to the general stress associated with weaning rather than to a specific stimulation. Accordingly, in rats an initial increase of IL-1 $\beta$ expression in Peyer's patches was found at $19 \mathrm{~d}$, and a further elevation at $21 \mathrm{~d}$ of age (the time of weaning), suggesting that this cytokine is involved in the differentiation and/or activation of epithelial cells at weaning ${ }^{(71,72)}$. TNF- $\alpha$, on the other hand, appears to be involved in the stimulation of $\mathrm{Cl}^{-}$secretion into the ileum ${ }^{(73)}$, suggesting that an increased expression of TNF- $\alpha$ might be implicated in the development of diarrhoea. Such early gene up-regulation of pro-inflammatory cytokines associated with weaning may contribute to early functional disorders, favouring the development of diarrhoea ${ }^{(27)}$. In a further study of Pié $e t a l .{ }^{(74)}$, the effect of enforced fasting ( $48 \mathrm{~h}$ ) on mRNA content of pro-inflammatory cytokines in the ileum and colon of newly weaned piglets was investigated, and no correlation between the quantity of feed intake and the mRNA content of the pro-inflammatory cytokines IL-1 $\beta$, IL- 6 and TNF- $\alpha$ could be observed at day 4 post-weaning. Other studies, however, reported that a lack of intestinal nutrient provision (i.e. parenteral feeding) favours the development of inflammation in the intestine of piglets ${ }^{(75,76)}$.

\section{Growth factors}

Several nutrient-regulated intestinal growth factors, such as insulin-like growth factor (IGF)-I, are associated with fasting-induced atrophy and refeeding-induced intestinal regrowth $^{(77)}$. Moreover, the administration of exogenous IGF-I has been noted to reverse the mucosal atrophy induced by TPN in rodents ${ }^{(78)}$. The IGF promote the proliferation and differentiation of cells in various organ systems, including intestinal epithelial cells ${ }^{(79)}$. Their biological actions are mediated by binding to specific cell surface receptors ${ }^{(80,81)}$, and are directly regulated by IGFbinding proteins (IGFBP) ${ }^{(79,82,83)}$. The IGF system, including IGF-I, IGF-II, the IGFBP and the IGF membrane-associated receptors, is highly sensitive to nutritional status ${ }^{(84)}$. In Table 2, some studies are summarised describing the effects of fasting/refeeding on growth factors. For example, fasting in rats decreased jejunal IGF-I mRNA levels and plasma IGF-I concentrations and induced intestinal atrophy ${ }^{(5)}$. These changes were reversed by refeeding. However, levels of IGF-I receptor and IGF-I receptor mRNA were not significantly altered during fasting, but they increased after refeeding. Such up-regulation of IGF-I and IGF-I receptor expression during refeeding suggests a role for the IGF action pathway in gut trophic responses to enteral nutrients. Other growth factor systems, such as the keratinocyte growth factor (KGF), stimulate, amongst others, the proliferation of intestinal epithelial cells ${ }^{(85,86)}$, and are also regulated by the nutritional status of the animal $^{(87)}$. However, in contrast to intestinal IGF-I and IGF-I receptor mRNA ${ }^{(5)}$, intestinal KGF and KGF receptor mRNA levels were up-regulated during fasting, and returned towards control values after ad libitum refeeding. The increase in KGF and KGF receptor mRNA may be an adaptive response to maintain intestinal cell proliferation during starvation, when the expression and action of other growth factor systems, i.e. IGF-I, are blunted ${ }^{(87)}$. Furthermore, it has been shown that the gene expression of several IGFBP changes in response to weaning. Different IGFBP show different patterns during postnatal development in the rat ${ }^{(88)}$ and also in the pig ${ }^{(89)}$. Such changes in the expression of the intestinal IGF system may be important for intestinal adaptive growth of the small-intestinal mucosa

Table 2. Changes in intestinal gene expression due to fasting/refeeding in rats: effect on growth factors

\begin{tabular}{|c|c|c|}
\hline Treatment & Effect & Reference \\
\hline Fasting, $72 \mathrm{~h}$ & $\begin{array}{l}\text { Jejunal IGF-I mRNA, plasma IGF-I concentration } \downarrow \\
\text { Intestinal atrophy } \uparrow \\
\text { IGF-I receptor, IGF-I receptor mRNA - }\end{array}$ & 5 \\
\hline Refeeding & $\begin{array}{l}\text { Changes reversed } \\
\text { IGF-I receptor, IGF-I receptor mRNA } \uparrow\end{array}$ & \\
\hline Fasting, $72 \mathrm{~h}$ & $\begin{array}{l}\text { lleal KGF, KGF receptor mRNA } \uparrow \\
\text { Colonic KGF receptor mRNA } \uparrow\end{array}$ & 87 \\
\hline Refeeding, ad libitum, $72 \mathrm{~h}$ & Return to control levels & \\
\hline Fasting, $72 \mathrm{~h}$ & Jejunal proglucagon mRNA $\downarrow$ & 6 \\
\hline Refeeding & Return to control levels & \\
\hline Fasting, $48 \mathrm{~h}$ & $\begin{array}{l}\text { Plasma IGF-I and GLP-2, jejunal mucosal cellularity (mass, protein, DNA, villous height), } \\
\text { jejunal IGF-I mRNA, ileal proglucagon mRNA } \downarrow\end{array}$ & 95 \\
\hline Refeeding, intragastric and ad libitum & Plasma GLP-2, jejunal IGF-I mRNA $\uparrow$, mucosal regrowth & \\
\hline
\end{tabular}

IGF, insulin-like growth factor; $\downarrow$, decrease; $\uparrow$, increase; -, no effect; KGF, keratinocyte growth factor; GLP, glucagon-like peptide. 
in response to weaning for protection against mucosal damage during, for example, inflammation ${ }^{(89)}$.

Glucagon-like peptides (GLP) represent the major secretory peptides derived from the post-translational processing of the proglucagon gene ${ }^{(90,91)}$. GLP-2 plays an essential role in maintaining the intestinal structure in the fed state, but also during adaptation in response to nutrient deprivation and subsequent feeding ${ }^{(92)}$. For young domestic animals, a potential therapeutic application of GLP-2 was suggested in periods of intestinal dysfunction and damage, such as during weaning and diarrhoeal diseases $^{(93)}$. Intestinal expression of proglucagon mRNA is influenced by the nutritional status of the animal. For example, in rats ${ }^{(6)}$ and mice ${ }^{(94)}$, fasting is associated with a decrease in intestinal proglucagon mRNA expression, while refeeding rapidly increases levels back to those of normal non-fasted controls (Table 2). Furthermore, in a study of Nelson et al. ${ }^{(95)}$ (Table 2), fasting in rats significantly decreased plasma concentrations of IGF-I and GLP-2, jejunal mucosal cellularity, IGF-I mRNA and ileal proglucagon mRNA. Upon intragastric and ad libitum refeeding, levels of plasma GLP-2 and jejunal IGF-I mRNA were elevated, accompanied by mucosal regrowth. This suggests that luminal nutrients stimulate intestinal growth, partly by an increased expression of both GLP-2 and IGF-I ${ }^{(95)}$. Furthermore, Petersen et al. ${ }^{(96)}$ found that enteral food supply decreased small-intestinal GLP-2 receptor mRNA abundance (which was highest at birth) in suckling and weaned pigs. The authors suggest that introduction of enteral feeding transiently increases plasma GLP-2 concentrations and decreases the levels of small-intestinal GLP-2 receptor mRNA during pig development. This emphasises the role of GLP-2 in the growth of the small intestine around birth and weaning due to a response to enteral nutrition.

\section{Influence of dietary components on intestinal gene expression}

Diet is a potent stimulant for altering the environment of cells in most organs, particularly in the GIT. A normal diet mainly consists of different proportions of carbohydrates, proteins and lipids, which may, along with vitamins and minerals, exert individual effects on intestinal gene expression ${ }^{(47)}$. In the following, examples are given where the major dietary constituents, i.e. carbohydrates, lipids and proteins/amino acids have been shown to affect intestinal gene expression. Besides, nutrients may escape digestion by mammalian enzymes in the small intestine. When present in the large-intestinal lumen, this material undergoes intense degradation by the colonic microflora resulting in the release of numerous bacterial metabolites. Fermentation of, for example, carbohydrates results, amongst others, in the production of SCFA ${ }^{(97)}$. With regard to SCFA, especially butyrate has been shown to have multiple effects on cultured mammalian cells that include inhibition of proliferation, induction of differentiation and induction or repression of gene expression ${ }^{(18)}$. However, other microbial metabolites also are able to influence intestinal gene expression. For example, polyamines, which originate, amongst others, from microbial proteolysis $^{(97)}$, but also from dietary sources, have been shown to modulate the expression of various genes involved in, for example, cell proliferation ${ }^{(98,99)}$ or apoptosis ${ }^{(100)}$. Polyamines are required for the stimulation of mucosal growth, in part, through their ability to regulate the expression of nuclear transcription factors ${ }^{(99,101,102)}$. Thus, in the following, reference will also be made to studies focusing on intestinal gene expression as mediated by bacterial metabolites.

\section{Protein and amino acids}

Digestive function and nutrient metabolism. Typically, specific dietary components can affect the activity and gene expression of digestive enzymes and transporters. For example, the expression of the oligopeptide transporter Pept1 varies according to diet composition. In rats, a high-protein diet (50\%) resulted in a two-fold increase of Pept1 mRNA levels as compared with animals fed a lowprotein diet $(4 \%)^{(103)}$ or a protein-free diet ${ }^{(104)}$. In the study of Shiraga et al. ${ }^{(104)}$, rats were fed a diet supplemented with a single dipeptide (Gly-Phe) and phenylalanine for $3 \mathrm{~d}$. The dipeptide and the amino acid enhanced transport activity, which was accompanied by an increase in Pept 1 mRNA and protein in intestinal mucosal cells. Also, treatment of human intestinal cells with the dipeptide glycyl-sarcosine resulted in an increased Pept1 mRNA abundance, enhanced transport rate of the dipeptide glycyl-glutamine ${ }^{(105)}$ and vice versa ${ }^{(106)}$. In conclusion, endproducts of protein digestion, for example, small peptides, seem to participate in pathways that control the expression of intestinal transporters such as Pept1. This may lead to increased transporter capacity in the digestive tract $^{(107)}$, and results in an increased peptide transport, a characteristic of intestinal adaptation to a high-protein $\operatorname{diet}^{(43,108)}$. Although a practical use of peptides in livestock nutrition is still lacking, results of these studies suggest better nutritional management. Providing a diet that best accommodates the profile of digestive enzymes and nutrient transporters in the gut will result in improved nutrient utilisation of dietary protein, reduced $\mathrm{N}$ excretion, improved health and growth of the animal ${ }^{(39)}$.

Furthermore, the intestinal peptide transport system is important for animals during the suckling period ${ }^{(109)}$. For example, Pept1 mRNA levels in the small intestine of rats increased rapidly from the early days to the middle of the suckling period, and then decreased from the middle to the end of the suckling period ${ }^{(110)}$. According to a study of Wang et al. ${ }^{(111)}$, Pept1 mRNA expression in the duodenum, proximal and distal jejunum of Tibetan piglets gradually increased from day 1 to the middle of the 
suckling period, and then gradually decreased from the middle to the end of the suckling period. The authors concluded that Pept1 gene expression was up-regulated by the onset of suckling colostrum or milk, which is rich in nutrients and growth factors, and thus the transport activity of the entire small intestine increased due to a dramatic increase in intestinal mucosal mass. However, from the middle to the end of the suckling period, the nutrients ingested by the piglets were limited by the milk yield of the sow, resulting in a decreased transport activity of the entire small intestine. Obviously, Pept1 mRNA expression along the small intestine is regulated according to age in early development, which may have major implications for amino acid and protein nutrition in young animals.

Dietary glutamine supplementation improves, amongst others, nutrient digestion and nutrient utilisation in earlyweaned piglets ${ }^{(112)}$. Wang et al. ${ }^{(7)}$ showed, in response to dietary glutamine supplementation to piglets weaned on d 21, effects on small-intestinal gene expression that would provide an idea for the beneficial effects of glutamine. By using microarray technology, Wang et al. ${ }^{(7)}$ found, for example, an increased expression of genes related to lipid metabolism, Fe absorption and regulation of nutrient metabolism. For example, an increased expression was found for endozepine, which is expressed in intestinal mucosal cells, and which, amongst other functions, acts like acyl CoA-binding protein, thus regulating lipid metabolism, assembly and trafficking across the small intestine ${ }^{(113,114)}$. Furthermore, an enhanced gene expression was observed for IL-13R- $\alpha-1$, which is part of a receptor binding IL-13. The cytokine IL-13 stimulates contractility of intestinal smooth muscle, thereby promoting gut motility ${ }^{(115)}$. This may support the movement of luminal digesta along the small intestine, thereby facilitating the digestion of macronutrients by digestive enzymes and absorption of the resulting smaller molecules by enterocytes. However, on the other hand, an increase in intestinal motility also may cause excessive fluid losses, due to an increased transit time ${ }^{(116)}$, which would then rather be a negative effect.

Immune function. In the study of Wang et al. ${ }^{(7)}$ with piglets weaned on day 21, the small-intestinal expression of several genes was down-regulated in response to dietary glutamine, including genes related to immune activation. However, there was an increased expression of genes related to defence against infection, such as IL-13R- $\alpha-1$, and endozepine. Porcine endozepine has been shown to exert a potent antibacterial activity in the porcine gut ${ }^{(117)}$, while IL-13 is a multi-functional cytokine involved in host defence against infection, for example, against protozoans ${ }^{(118)}$. As early weaning is often associated with immunological challenges in the intestine ${ }^{(119)}$, elevated expression of, for example, endozepine in glutamine-supplemented diets for piglets may thus protect the gut from infections during weaning. Altogether, this study ${ }^{(7)}$ provides evidence for a possible molecular mechanism which would explain previous findings according to which dietary glutamine supplementation prevents intestinal dysfunction and enhances growth performance of early-weaned piglets ${ }^{(112)}$

Arginine is a non-essential amino acid that has attracted interest because it plays an important role in many physiological and biological processes including physiology of the $\mathrm{GIT}^{(120)}$. It has been shown to be effective in a number of gut injury models ${ }^{(121,122)}$. In a study of Liu et al. ${ }^{(123)}$, dietary arginine supplementation alleviated intestinal mucosal disruption induced by Escherichia coli lipopolysaccharide (LPS) in weaned pigs. In this study, $0.5 \%$ arginine prevented the elevation of jejunal and ileal TNF- $\alpha$ mRNA abundance, and $1.0 \%$ arginine alleviated the elevation of jejunal IL- 6 mRNA and TNF- $\alpha$ mRNA abundance induced by LPS challenge. There was also a tendency for increased PPAR- $\gamma$ mRNA abundance in the duodenum, jejunum $(P<0.05)$ and ileum due to arginine supplementation. These results indicate that arginine supplementation has beneficial effects in alleviating gut mucosal injury induced by LPS challenge, possibly by decreasing the expression of intestinal pro-inflammatory cytokines through activating PPAR- $\gamma$ expression. PPAR- $\gamma$ is a transcription factor and has been recognised as an endogenous regulator of intestinal inflammation ${ }^{(124)}$. PPAR- $\gamma$ ligands have been shown to be effective in intestinal inflammatory models ${ }^{(125)}$. The protective effects of PPAR- $\gamma$ and its ligands are associated with the inhibition of inflammatory indices such as pro-inflammatory cytokines ${ }^{(126)}$. The inhibitory effect of PPAR- $\gamma$ on pro-inflammatory cytokines could be mediated through the inhibition of transcription factor $\mathrm{NF}-\mathrm{KB}^{(127,128)}$.

\section{Lipids}

Digestive function and nutrient metabolism. Lipids of dietary origin can be involved in the regulation of expression of genes related to digestion and nutrient transport. For example, in a study of Yasutake et al. ${ }^{(129)}$, 6-week-old rats were fed either a diet high in mediumchain TAG (MCT), a diet high in long-chain TAG or a highcarbohydrate diet. As compared with the long-chain TAG diet, the MCT diet as well as the carbohydrate diet resulted in jejunal elevation of mRNA of sucrase-isomaltase, and of Na-coupled glucose co-transporter-1 (SGLT1), by which glucose enters the epithelial cells via active transport ${ }^{(130)}$ Force-feeding the MCT or a high-sucrose diet evoked a marked increase in sucrase-isomaltase mRNA and SGLT1 mRNA levels within $12 \mathrm{~h}$, as compared with force-feeding a long-chain TAG diet. This suggests that not only carbohydrate intake but also MCT intake might influence jejunal sucrase-isomaltase mRNA and SGLT1 mRNA levels, probably through a generation of common metabolite(s) of carbohydrates and $\mathrm{MCT}^{(129)}$. According to the study of Yasutake et al. ${ }^{(129)}$, glycerol as such a metabolite originating from MCT might enter the glycolytic pathway and mimic the effect of a high-carbohydrate diet. 
Furthermore, the high lipid content of mother's milk might play a role in intestinal gene expression of newborn animals. For example, in neonatal piglets given a high-TAG intraduodenal infusion for $24 \mathrm{~h}$, jejunal apoA-IV expression increases 7 -fold at the pretranslational level in comparison with control animals given a low-TAG infusion ${ }^{(131,132)}$. ApoA-IV is expressed in the small intestine and plays a role in lipid absorption, transport and metabolism ${ }^{(133)}$. In the older, suckling piglet, only a two-fold increase could be shown. This might be of importance in the newborn receiving a high-fat milk diet, when apoA-IV may play a role in facilitating enterocyte lipid transport under such conditions of high lipid flux ${ }^{(134)}$. More recently, it has been shown in developing rats ${ }^{(135)}$ that fatty acids in mother's milk induce gene expression of the liver-type fatty acid-binding protein (L-FABP) and cellular retinolbinding protein type II (CRBPII), which are cytosolic binding proteins for fatty acids and vitamin A, facilitating their absorption from lumen to the enterocytes. In this study, jejunal mRNA levels of PPAR- $\alpha$ were increased during the suckling period. Furthermore, the authors examined the expression of these genes following oral administration of a range of fatty acids, namely caprylic acid, oleic acid, linoleic acid and arachidonic acid, all of which are components of the milk of weaning rats. PPAR- $\alpha$, L-FABP and CRBPII were induced by caprylic and oleic acids to similar extents. The results of this study indicate that the expression of small-intestinal L-FABP and CRBPII genes in postnatal development is regulated by a change in expression of PPAR- $\alpha$ which transmits the signalling of fatty acids derived from milk ${ }^{(135)}$. For the young animal, this suggests that fatty acids in milk may help to ensure the effective absorption of dietary fat and vitamin A.

Immune function. Several studies have been performed investigating the effects of dietary lipids on intestinal gene expression with regard to immunological parameters, mostly directed to intestinal inflammation. According to a study with rats ${ }^{(136)}$, MCT enhanced secretory IgA (sIgA) expression in the ileum compared with rats given maize oil. After LPS challenge, expression of sIgA was decreased in the maize oil group but not in the MCT group. Furthermore, MCT administration resulted in a decreased expression of pro-inflammatory cytokines (TNF- $\alpha$ and IL-18), and an increased expression of IgA-promoting cytokines (IL-6, IL-10), together with lower mRNA expression of the IgA-inhibiting cytokine IFN- $\gamma$. Since sIgA plays an important role in protection against infections in the intestinal immune system, an enhanced sIgA production is thought to be beneficial for the organism ${ }^{(137)}$. Obviously, dietary MCT can reduce intestinal injury after endotoxin administration by inhibition of the expression of some inflammatory cytokines and enhancing intestinal $\operatorname{sIg} \mathrm{A}^{(136)}$.

Furthermore, effects on intestinal gene expression have been shown in several studies investigating the anti-inflammatory effects of dietary conjugated linoleic acid (CLA) (Table 3). Hontecillas et al. ${ }^{(138)}$ could show in pigs with induced colitis that supplementation with CLA before the induction of colitis decreased mucosal damage and maintained cytokine expression and lymphocyte subset distribution similar to that in non-infected pigs. Furthermore, CLA supplementation led to an enhanced colonic expression of PPAR- $\boldsymbol{\gamma}$. Accordingly, Bassaganya-Riera et al. ${ }^{(139)}$ found amelioration of colitis in mice due to CLA-supplemented diets, mediated through a PPAR- $\boldsymbol{\gamma}$ dependent mechanism. PPAR- $\gamma$ belongs to a group of transcription factors that are sensitive to dietary fatty acids ${ }^{(12)}$, and thus may translate nutritional stimuli into changes in gene expression ${ }^{(11)}$. Activators of PPAR- $\gamma$ have been shown to inhibit the activation of a number of inflammatory genes ${ }^{(13,14)}$. The anti-inflammatory actions of PPAR may occur via stimulation of the breakdown of inflammatory eicosanoids through the induction of peroxisomal $\beta$-oxidation ${ }^{(140,141)}$. However, they may also interfere with or antagonise the activation of other transcription factors, including $\mathrm{NF}-\mathrm{\kappa B}^{(142)}$, thereby suppressing the expression of pro-inflammatory cytokines (i.e. TNF- $\alpha$, IL-6 and IL- $1 \beta)^{(128)}$. In a further study of Bassaganya-Riera \& Hontecillas $^{(143)}$, using a pig model with induced colitis, dietary CLA supplementation up-regulated colonic PPAR- $\gamma$ expression and contributed to a delay in the onset of induced colitis and an attenuated growth depression in

Table 3. Effect of dietary conjugated linoleic acid supplementation on gene expression related to immune function in pigs

\begin{tabular}{|c|c|c|}
\hline Weight and age of pigs, tissue, challenge & Effect & Reference \\
\hline Pigs, $4.8-5.5 \mathrm{~kg}$, bacterial-induced colitis & $\begin{array}{l}\text { Cytokine expression (IL-10, IFN- } \gamma \text { ), lymphocyte subset distribution } \\
\left(\mathrm{CD}^{+}, \mathrm{CD}^{+}\right) \text {similar to non-infected pigs } \\
\text { Mucosal damage } \downarrow \\
\text { Colonic expression of PPAR- } \gamma \uparrow\end{array}$ & 138 \\
\hline Pigs, $15 \mathrm{~d}$ old, induced colitis & $\begin{array}{l}\text { TNF- } \alpha \downarrow \\
\text { Growth depression } \downarrow \\
\text { Delayed onset of colitis } \\
\text { Colonic expression of PPAR- } \gamma \uparrow\end{array}$ & 143 \\
\hline $\begin{array}{l}\text { Pigs, } 7.8-8.3 \mathrm{~kg} \text {, spleen and thymus, } \\
\text { challenged with LPS }\end{array}$ & $\begin{array}{l}\text { IL- } 6 \text { mRNA, TNF- } \alpha \text { mRNA } \downarrow \\
\text { IL-10 mRNA } \uparrow \\
\text { PPAR } \gamma \text { mRNA } \uparrow\end{array}$ & 144 \\
\hline
\end{tabular}

IFN, interferon; $\downarrow$, decrease; $\uparrow$, increase; LPS, lipopolysaccharides. 
the pigs, coupled with down-regulation of TNF- $\alpha$. Similarly, Changhua et al. ${ }^{(144)}$ found that dietary CLA attenuated the production and expression of pro-inflammatory cytokines in the spleen and thymus of weaned pigs challenged with LPS, mediated at least in part through a PPAR- $\gamma$ dependent mechanism, together with an enhanced production and expression of the anti-inflammatory cytokine IL-10. These studies suggest the potential of dietary CLA in alleviating mucosal damage originating from intestinal inflammation, thereby possibly improving overall gut health.

\section{Carbohydrates}

Digestive function and nutrient metabolism. Many studies have shown that feeding a high-carbohydrate diet induces the intestinal expression of genes related to carbohydrate digestion and absorption, including disaccharidases and monosaccharide transporters ${ }^{(145,146)}$. For example, upon the introduction of a high-starch diet to rats, both sucrase and lactase activities were elevated, accompanied by the accumulation of the respective $\mathrm{mRNA}^{(129,147)}$. Also, expression of the SGLT1 gene is upregulated by feeding rodents a carbohydrate-rich diet $^{(129,146)}$. Furthermore, dietary fructose (or a metabolite of it) leads to an increase in the transcripts of sucraseisomaltase and lactase genes in rats, as well as for the transcripts of the transporter (GLUT5) genes ${ }^{(145,146)}$. Thus, transcriptional regulation is involved in the dietary adaptation of the carbohydrate digestion/absorption-related genes, and regulation of enzymes and transporters seems to be linked to each other ${ }^{(148)}$. However, according to a study of Cui et al. ${ }^{(149)}$, using microarray hybridisation and relative quantitative reverse transcription-PCR, a wide range of genes changed in their expression in response to a fructose perfusion of the rat small intestine. Along with expression of the intestinal brush-border fructose transporter GLUT5, expression of more than twenty genes increased considerably, including two gluconeogenic enzymes, glucose-6-phosphatase and fructose-1,6bisphosphatase, and fructose-2,6-bisphosphatase, an enzyme unique to fructose metabolism and regulating fructose-1,6-bisphosphatase activity. Furthermore, not only genes related to sugar metabolism and transport, but also other genes changed their expression in response to high fructose perfusion, for example, transcription factors. This shows that many signalling and metabolic pathways in the small intestine are responsive to the presence of one single nutrient, i.e. in this case fructose, in the intestinal lumen. In addition, it has been shown in rats that the intestine is fructose insensitive before approximately age $14 \mathrm{~d}$, i.e. GLUT5 can be regulated by fructose when pups are weaning but not when pups are suckling ${ }^{(150)}$. Thus, the ontogenic development of the intestine determines when substrate regulation of GLUT5 can occur. GLUT5 is a model of developing transporter systems in the small intestine, as it has sharply defined stages that are characterised by differences in the ability of its substrate to regulate GLUT5 transcription. Furthermore, it was shown that a premature induction of GLUT5 expression and fructose uptake can be induced by glucocorticoids in suckling rats aged $10 \mathrm{~d}^{(151)}$. Biologically, this could mean that, in case the mother is under stress, it may release high levels of glucocorticoids with the milk ${ }^{(152)}$ that subsequently and prematurely enable the small intestine of the young to digest and absorb nutrients from the environment, thereby improving its survival rate in the event of the loss of the mother. This indicates developmental plasticity providing the ability of the intestine to change function in response to environmental cues ${ }^{(151)}$. Although these studies have been performed with rats, they provide valuable information for dietary regulation of nutrient digestion and transport by their respective substrates, but also that specific nutrients are able to influence intestinal gene expression beyond their own metabolism. Furthermore, with regard to GLUT5 regulation, it becomes clear that several factors may be involved in regulatory mechanisms, i.e. substrate and age, but that there also exists the possibility to modify regulatory mechanisms by external factors, for example, by diet.

\section{Fermentable carbohydrates}

Digestive function and nutrient metabolism. Tako et $a l^{(153)}$ assessed the effect of dietary inulin (4\%) on the gene expression of selected intestinal Fe transport proteins in anaemic piglets (aged 5 weeks, injected with only half of the normal Fe dose, $50 \mathrm{mg}$ Fe as Fe-dextran), using semiquantitative RT-PCR analyses (Table 4). In this study, mRNA levels of intestinal Fe transporters, enzymes and binding proteins in duodenal samples were significantly higher in the inulin group compared with the control. In the colon, expression of the pig divalent metal transporter 1 , transferrin receptor and ferritin significantly increased for the inulin group as well. Furthermore, a 100\% increase in duodenal mucin mRNA level was observed for the inulin group. For fermentable carbohydrates such as inulin, it can be assumed that they may undergo microbial fermentation in the large intestine leading to the production of SCFA $^{(19,97)}$, although considerable amounts may already be fermented before the distal ileum ${ }^{(154,155)}$. Although SCFA concentrations were not determined in the study of Tako et al. ${ }^{(153)}$, there were significant increases in caecal populations of lactobacilli and bifidobacteria, suggesting also a possible effect on SCFA concentrations. Thus, according to the authors, one possible pathway by which inulin might affect intestinal gene expression would be via an increased SCFA production in the colon leading to a possible systemic effect of butyrate on Fe metabolism.

Immune function. An example for the modification of inflammatory conditions by dietary means is provided by a study of Kanauchi et al. ${ }^{(156)}$ in mice with induced colitis 
Table 4. Effect of dietary supplementation with fermentable carbohydrates on intestinal gene expression in piglets

\begin{tabular}{|c|c|c|c|}
\hline Fermentable carbohydrate & Intestinal segment & Effect & Reference \\
\hline \multicolumn{4}{|l|}{ Nutrient absorption } \\
\hline \multirow[t]{2}{*}{ Inulin (4\%) } & Duodenum & $\begin{array}{l}\text { Divalent metal transporter } 1 \text {, duodenal } \\
\text { cytochrome-b reductase, ferroportin, ferritin, } \\
\text { transferrin receptor mRNA } \uparrow\end{array}$ & 153 \\
\hline & Colon & $\begin{array}{l}\text { Divalent metal transporter } 1 \text {, transferrin receptor, } \\
\text { ferritin mRNA } \uparrow\end{array}$ & \\
\hline \multicolumn{4}{|l|}{ Immune function and growth factors } \\
\hline $\begin{array}{l}\text { Lactulose, inulin, sugarbeet pulp, } \\
\text { wheat starch }\end{array}$ & Colon & $\begin{array}{l}\text { IL-6 mRNA } \uparrow \\
\text { IL-1 } \beta \text { mRNA } \uparrow \text { (also control) }\end{array}$ & 74 \\
\hline \multirow[t]{2}{*}{$\begin{array}{l}\text { Galacto-mannan-oligosaccharides, } \\
\text { chitosan oligosaccharides }\end{array}$} & $\begin{array}{l}\text { Jejunal mucosa, mesenteric } \\
\text { lymph nodes }\end{array}$ & IL- $1 \beta$ mRNA $\uparrow$ & 157 \\
\hline & Serum & $\mathrm{IL}-1 \beta, \mathrm{IL}-2, \mathrm{IL}-6 \uparrow$ & \\
\hline Wheat bran & Stomach, jejunum & NF-кB mRNA $\uparrow$ & 159 \\
\hline \multirow[t]{2}{*}{ Chinese pine pollen } & Colon & $\begin{array}{l}\text { NF-kB, TNF- } \alpha \text {, TGF- } \beta \text {, caspase } 3 \text {, CDK4, } \\
\text { IGF-I mRNA } \downarrow\end{array}$ & \\
\hline & Mesenterial lymph nodes & NF-кB, TGF- $\beta$ mRNA $\uparrow$ & \\
\hline
\end{tabular}

$\uparrow$, Increase; TGF, transforming growth factor; IGF, insulin-like growth factor; $\downarrow$, decrease

that were fed a diet containing germinated barley (defined as a prebiotic product rich in hemicelluloses, which also contains glutamine-rich protein). This dietary treatment prevented disease activity after induction of colitis, associated with increased caecal butyrate concentration, decreased serum IL-6 levels as well as a tendency for reduced NF- $\mathrm{KB}$ expression. The authors suggest that the anti-inflammatory effects of the germinated barley may be due to increased butyrate production, possibly mediated via inhibition of NF-кB.

In Table 4, studies pertaining to effects of dietary supplementation with fermentable carbohydrates on intestinal gene expression in pigs are summarised. For example, Pié et $a l .{ }^{(74)}$ investigated the effect of added fermentable carbohydrates on the mRNA content of several pro-inflammatory cytokines (for example, IL-1 $\beta$, IL-6, IL-8, IL-18, $\mathrm{TNF}-\alpha$ ) in the ileum and colon of newly weaned piglets. Fermentation endproducts were also assessed. The carbohydrate-enriched diet induced an up-regulation of IL-6 mRNA content in the colon of piglets $4 \mathrm{~d}$ post-weaning, which was not observed for the piglets fed the control diet. This indicates that the regulation of IL- 6 mRNA in the colon depends on dietary factors, or at least on microbiological factors that have been influenced by the diet. However, in this study, comparisons of IL-6 mRNA contents with SCFA (acetic, propionic and butyric acids) concentrations in the ileum and colon showed no correlations, indicating that the increased level of this cytokine was not directly dependent of the presence of SCFA. In addition, an increase in IL-1 $\beta$ mRNA was observed at day 4 post-weaning in piglets fed the carbohydrate diet, and also in the control group, suggesting that the level of this cytokine is not influenced by diet composition. In another study with piglets ${ }^{(27)}$, a rapid increase in IL-1 $\beta$ after weaning was obtained. Obviously, the observed responses are more general, i.e. reflecting early immunological changes associated with weaning, or other stress, in piglets. A further study with piglets (aged $15 \mathrm{~d}$ ) fed fermentable carbohydrates showed enhanced IL-1 $\beta$ mRNA levels in the jejunal mucosa and mesenteric lymph nodes, as well as increased serum levels of $\mathrm{IL}-1 \beta^{(157)}$. Consistently, serum levels of IL-2 and IL- 6 in piglets fed the carbohydrates were higher than in control animals. The authors suggested that such an increase in inflammatory cytokines may result from activation of some intestinal bacteria which then stimulated an immune defence response ${ }^{(158)}$. Schedle et $a l .{ }^{(159)}$ used a piglet model to investigate the immunological response of gastrointestinal tissues to dietary additions of insoluble fibre, either wheat bran (rich in cellulose and hemicelluloses) or pine pollen (rich in lignin), measured as relative mRNA expression levels of different transcription factors (NF-кB), inflammatory marker genes (TNF- $\alpha$, TGF- $\beta$ ), as well as markers of the cell cycle (caspase 3, CDK4) and growth factors (Table 4). According to this study, NF- $\kappa \mathrm{B}, \mathrm{TNF}-\alpha$, TGF- $\beta$ and caspase 3 were up-regulated in the proximal part of the GIT due to supplemental wheat bran, suggesting that the impact of insoluble dietary fibre is not limited to the colon. Furthermore, due to a down-regulation of NF- $\mathrm{KB}$ in the colon caused by pine pollen, the authors suggested a reduction in pro-inflammatory action in colonic tissue. In this study, Schedle et al. ${ }^{(159)}$ also measured morphological parameters, and found an increased villous height of the mucosa in the jejunum and ileum due to insoluble dietary fibre. In addition, TGF- $\beta$ was up-regulated in the stomach and jejunum by insoluble fibre, which is in line with a pronounced cell proliferation and an increase in villus size. They concluded that additions of insoluble fibre rich in lignin might significantly contribute to GIT stability, in terms of increased cell proliferation and reduced inflammation in weaning piglets, however, not only with regard to the colon, but rather to the entire digestive tract. 
However, the insoluble fibre used in this study appeared to be not fermentable. So, no relationships to bacterial metabolites were drawn and the primary mode of action remains unclear.

Growth factors. Several studies in, for example, rats and dogs ${ }^{(160,161)}$ have shown that diets supplemented with fermentable carbohydrates up-regulate the levels of intestinal proglucagon mRNA, as well as the amount of proglucagon-derived peptides (PGDP), when compared with diets containing no or a low content of fermentable carbohydrates (Table 5). The increase in intestinal proglucagon expression is probably due to carbohydrate fermentation in the colon and its simultaneous production of SCFA $^{(162-164)}$. Indeed, SCFA are known to increase proglucagon mRNA in the ileum of rats ${ }^{(165,166)}$. With regard to the various physiological effects of intestinal PGDP, for example, intestinotrophic function, a stimulation of intestinal PGDP synthesis and secretion by ingestion of specific dietary components might be of interest during disease or intestinal insufficiency. For GLP-1, but also for GLP-2, it seems that there is the possibility to modulate its endogenous availability via an enhanced production of the precursor proglucagon mRNA through the ingestion of fermentable carbohydrates ${ }^{(167-170)}$.

\section{Bacterial community and metabolites}

Microbiota-host interactions. Extensive cross-talk between the microbiota and the intestinal epithelium takes place, and the intestinal microbiota influences the GIT and the host as such ${ }^{(171)}$. Thus, modulation of the bacterial community by dietary ingredients, such as carbohydrate sources ${ }^{(172)}$, can have sustainable effects on intestinal development and integrity. For instance, activities of brush-border enzymes, such as disaccharide hydrolases, peptidases and alkaline phosphatase, which are markers of enterocyte differentiation, are modified by intestinal bacterial colonisation ${ }^{(173,174)}$. In gnotobiotic animals, i.e. germ-free animals colonised with one or a few bacterial species, the effects of individual bacterial strains or defined groups of strains on the host epithelium can be investigated. For instance, Hooper et al. ${ }^{(175)}$ used a gnotobiotic mouse model to examine gene expression responses following monoassociation with Bacteroides thetaiotaomicron. Using DNA microarrays, laser-capture microdissection and quantitative RT-PCR, Hooper et al. ${ }^{(175)}$ determined that $B$. thetaiotaomicron modulated the expression of seventy-one intestinal genes involved in nutrient absorption, mucosal barrier fortification, xenobiotic metabolism, angiogenesis and postnatal intestinal maturation. Colonisation of conventional mice with Lactobacillus paracasei spp. paracasei F19 or L. acidophilus NCFB 1748 induced significant regulation of twenty-two and fifty-five genes involved in essential physiological functions such as the immune response, regulation of energy homeostasis and host defence in the distal ileum, respectively, whereas only twenty genes were regulated by both strains ${ }^{(176)}$. Using a neonatal pig model, Siggers et $a l^{(174)}$ showed that monoassociation of pigs with L. fermentum stimulated the prohormone proglucagon expression, whereas monoassociation with E. coli decreased it. Many cleaved peptides from proglucagon have important biological activities, such as GLP-2 that is involved in epithelial proliferation, decreased epithelial apoptosis and increased nutrient absorption ${ }^{(177)}$. Moreover, Willing \& Van Kessel ${ }^{(178)}$ demonstrated that association of neonate piglets with conventional bacteria or monoassociation with $E$. coli but not with $L$. fermentum increased overall cell turnover in the small intestine by stimulating increased apoptosis through the expression of death ligand Fas ligand and TNF- $\alpha$ and by increasing cell proliferation. Throughout the GIT the most significant molecular function affected by the microbiota is the activity of proteins involved in defence or immune responses ${ }^{(171)}$, and all genes with this annotation are up-regulated in the small and large intestines of conventional mice and piglets compared with germ-free animals ${ }^{(179,180)}$. When germ-free piglets were conventionalised, epithelial inflammatory

Table 5. Effect of fermentable carbohydrates on intestinal proglucagon gene expression and proglucagon-derived peptide production

\begin{tabular}{|c|c|c|c|}
\hline Fermentable carbohydrate & Species and intestinal segment & Effect & Reference \\
\hline $\begin{array}{l}30 \% \text { fibre diet, } 14 \mathrm{~d} \text { (pea, oat, sugarbeet, } \\
\text { xanthan gum) ( } v . \text { fibre-free diet) }\end{array}$ & Rat, ileum & $\begin{array}{l}\text { Proglucagon mRNA } \uparrow \\
\text { Circulating GLP-1 and insulin } \uparrow \\
\quad \text { (after glucose challenge) }\end{array}$ & 162 \\
\hline Rhubarb fibre diet $(50 \mathrm{~g} / \mathrm{kg}), 14 \mathrm{~d}$ ( $\mathrm{v}$. cellulose) & Rat, ileum & Proglucagon mRNA $\uparrow$ & 222 \\
\hline $\begin{array}{l}\text { High-fermentable fibre diet (sugarbeet pulp, } \\
\text { gum arabic, fructo-oligosaccharide), } 14 \mathrm{~d} \\
\text { ( } v . \text { cellulose) }\end{array}$ & Dog, ileum & $\begin{array}{l}\text { Proglucagon mRNA } \uparrow \\
\text { GLP-1 } \uparrow\end{array}$ & 160 \\
\hline $30 \%$ fibre diet, $14 \mathrm{~d}$ ( $v$. fibre-free diet) & $\begin{array}{l}\text { Wild-type and transgenic mice, } \\
\text { colon, jejunum and ileum }\end{array}$ & Endogenous murine proglucagon mRNA $\uparrow$ & 94 \\
\hline $\begin{array}{l}\text { Oligofructose-enriched diet (10\%), } 3 \text { weeks } \\
\quad \text { (v. standard diet) }\end{array}$ & Rat, proximal colon & $\begin{array}{l}\text { Proglucagon mRNA } \uparrow \\
\text { GLP-1 } \uparrow\end{array}$ & 161 \\
\hline Oligofructose-enriched (10\%) high-fat diet & $\begin{array}{l}\text { Rat, caecum and colon } \\
\text { Proximal colon }\end{array}$ & $\begin{array}{l}\text { Proglucagon mRNA } \uparrow \\
\text { GLP-1 } \uparrow, \text { GLP-2 } \uparrow\end{array}$ & 169 \\
\hline
\end{tabular}

$\uparrow$, Increase; GLP, glucagon-like peptide. 
responses were detected in the ileum using high-density porcine oligonucleotide microarrays. Genes involved in epithelial cell turnover, mucus biosynthesis and priming of the immune system were induced. Receptors and transcription factors related to IFN-inducible genes were upregulated; however, at the same time, the inflammatory response seemed to be controlled through activation of genes in pathways that prevent excessive inflammation, supporting the concept of a homeostatic epithelium that maintains a tight intestinal barrier without producing excessive inflammatory responses, which would compromise barrier function ${ }^{(181)}$. Overall, the microbiota affects a multitude of epithelial functions in the intestine as a consequence of specific bacterial-host interactions, and these extend far beyond the immune response (for a review, see Leser \& Mølbak $\left.{ }^{(171)}\right)$.

SCFA. The ability of SCFA, particularly butyrate, to influence gene expression is increasingly considered. One well-known mechanism of butyrate to influence gene expression is via the induction of histone hyperacetylation through the inhibition of histone deacetylase (HDAC). By this means, the compactness of the histone is reduced, and the DNA is more accessible to transcription factors ${ }^{(182,183)}$. Among the different SCFA with different chain lengths, butyrate is most effective in inhibiting HDAC activity ${ }^{(182,184)}$. In Table 6, in vitro studies using cultured intestinal cells to investigate the influence of butyrate on cytokine gene expression are summarised. This might be of special importance with regard to inflammatory diseases, as particularly butyrate has been shown to suppress intestinal inflammation (for example, Harig et al. ${ }^{(185)}$ ). For example, colonic secretion of IL-8, a chemotactic and activating peptide for neutrophils ${ }^{(186,187)}$, is increased in human ulcerative colitis ex vivo, but is suppressed by butyrate ${ }^{(188)}$. A possible molecular mechanism to mediate the effects of butyrate is via modification of transcription factor activation. Segain et al. ${ }^{(189)}$ showed in LPS-stimulated lamina propria mononuclear cells, and in the colonic mucosa of mice with induced colitis that butyrate prevented the nuclear translocation of NF- $\mathrm{kB}$. The inhibitory effect of butyrate on NF- $\mathrm{KB}$ activation was also confirmed by Zapolska-Downar et al. ${ }^{(190)}$ in endothelial cells. It seems that the anti-inflammatory effects of butyrate - at least in part - are mediated via inhibition of NF- $\mathrm{B}^{(189)}$ which regulates the expression of genes involved in the inflammatory response, for example, cytokines such as $\mathrm{TNF}^{(191)}$. It has been proposed that the inhibitory effect of butyrate on NF- $\mathrm{KB}$ activation originates from its ability to inhibit HDAC activity ${ }^{(192)}$. On the other hand, Weber \& Kerr ${ }^{(193)}$ could not find in vivo effects of dietary sodium butyrate on the ileal relative abundance of cytokine mRNA (IL-6, TNF- $\alpha$ ) in weanling pigs challenged with E. coli LPS. This is in contrast to Milo et al. ${ }^{(194)}$ who found in young pigs that parenterally fed SCFA increased intestinal IL-6 abundance. Weber \& Kerr ${ }^{(193)}$ hypothesised that due to the anti-inflammatory activity of butyrate ${ }^{(195)}$ and other HDAC inhibitors ${ }^{(196)}$, butyrate might decrease the cytokine response to LPS. The lack of response in the study of Weber \& $\operatorname{Kerr}^{(193)}$ could be due to the different routes of administration for butyrate, or could be due to the fact that Milo et al. ${ }^{(194)}$ used a combination of SCFA.

With regard to effects on growth factors, it has been shown in vitro that butyrate, and to a lesser extent other SCFA, increased the synthesis of IGFBP-2 by the intestinal epithelial cell line Caco-2 (via histone acetylation). Simultaneously, synthesis of IGFBP-3, which is predominantly secreted in the absence of SCFA, is decreased ${ }^{(197)}$. Changes in IGFBP secretion corresponded to mRNA accumulation. Altering the profile of IGFBP may have profound effects on the bioavailability of IGF-I and IGF-II. Obviously, epithelial cells respond to bacterial products, i.e. SCFA, by secreting proteins that may modulate factors that affect their own proliferation and that of other intestinal cell types ${ }^{(197)}$. With regard to the proliferative effects of the IGF system, for example, on intestinal epithelial cells, it has been suggested that changes in the expression of IGF-I, IGF-IR and IGFBP in the intestine may play an important role in limiting mucosal damage or promoting tissue repair. This might be of importance for the adaptive function of the small intestine in response to weaning and during inflammation ${ }^{(89,198)}$.

Polyamines. Expression of enzymes and transporters related to digestion and absorption may also be influenced by polyamines ${ }^{(199)}$, originating from microbial proteolysis ${ }^{(97)}$,

Table 6. Influence of butyrate on cytokine gene expression of cultured intestinal cells

\begin{tabular}{|c|c|c|c|}
\hline Cells used & Treatment & Effect & Reference \\
\hline HIMEC & Sodium butyrate, stimulation with LPS & $\begin{array}{l}\text { IL-6 mRNA, IL-6 } \downarrow \\
\text { IL-8 mRNA - }\end{array}$ & 223 \\
\hline Intestinal epithelial cells (Caco-2) & Sodium butyrate, stimulation with IL-1 $1 \beta$ or LPS & IL-8 mRNA, IL-8 $\uparrow$ & 224 \\
\hline Intestinal epithelial cells (Caco-2) & Butyrate, resting cells or stimulation with IL-1 $\beta$ & $\begin{array}{l}\text { IL-8 mRNA, IL-8 } \uparrow \\
\text { MCP-1 mRNA, MCP-1 } \downarrow\end{array}$ & 184 \\
\hline $\begin{array}{l}\text { Intestinal biopsy specimens and isolated } \\
\text { lamina propria mononuclear cells from } \\
\text { Crohn's disease patients }\end{array}$ & Butyrate & $\begin{array}{l}\text { TNF- } \beta \text { mRNA, TNF, IL-6 mRNA, } \\
\text { IL-6, IL-1 } 1 \beta \text { mRNA, IL-1 } \beta \downarrow\end{array}$ & 189 \\
\hline Peripheral blood mononuclear cells & Butyrate, stimulation with LPS & $\begin{array}{l}\text { TNF- } \alpha \text { mRNA, TNF- } \beta \text { mRNA, TNF, } \\
\text { IL- } 6 \text { mRNA, IL- } 1 \beta \text { mRNA } \downarrow\end{array}$ & \\
\hline
\end{tabular}

HIMEC, human intestinal microvascular endothelial cells; LPS, lipopolysaccharide; $\downarrow$, decrease; -, no effect; $\uparrow$, increase; MCP-1, monocyte chemoattractant protein-1. 
or from dietary sources ${ }^{(200)}$, for example, from mother's milk $^{(201)}$. In a study of Wild et al. ${ }^{(199)}$, it has been shown that oral polyamine administration may modify the ontogeny of hexose transporter gene expression in the postnatal rat intestine. In this study, the polyamine spermidine, supplied at a level similar to the concentration in rat breast milk ${ }^{(202)}$, increased the abundance of mRNA for sucrase-isomaltase, SGLT1 and GLUT2, as well as ornithine decarboxylase (ODC) activity and protein and mRNA abundance. The maturational changes in enzyme expression have been correlated to both mucosal polyamine levels and to the onset of the expression and activity of ODC, the key enzyme of polyamine biosynthesis ${ }^{(203)}$. The study of Wild et al. ${ }^{(199)}$ suggests that normal ontogenic expression of the digestion and absorption of glucose may be modified by an exogenous polyamine (spermidine), acting through the increase in ODC activity, which, in turn, enhances the mRNA and protein abundance of the enzymes and transporters involved in this process.

Furthermore, polyamines originating from microbial proteolysis may be involved in the expression of genes related to the innate immune system. Chen et al. ${ }^{(204)}$ showed in vitro, by use of a cell line from the normal rat small intestine (IEC-6 cell line), that polyamines are necessary for Toll-like receptor (TLR)2 expression. Intestinal epithelial cells (IEC) express a variety of potential sensing receptors, including TLR, which are fundamental components of the innate immune response and allow mammalian intestinal epithelium to detect various microbes and different pathogens ${ }^{(205,206)}$. Thus, the polyamine-modulated TLR2 activation plays an important role in the regulation of the epithelial barrier function. It seems that polyamines are crucial for the maintenance of the epithelial barrier integrity and mucosal homeostasis under physiological conditions ${ }^{(204)}$.

Limitations and strengths of gene expression to determine implications of nutrition during weaning

Research has focused on mechanisms controlling gene expression, and the impact of biological and external factors on gene expression. Before the genomic approach was introduced in science, molecular biology aimed at investigating single genes or proteins, and their structure and function, in isolation from the larger context of other genes. The limitation of this approach is the need for a working hypothesis. Furthermore, it appears that physiological processes are governed by several genes acting in concert rather than by only one or a few individual genes. Genomic technologies such as array technology and large-scale DNA sequencing techniques facilitated the analysis of thousands of genes or proteins or metabolites in a single experiment (genomic approach). This approach is generating hypotheses and allows the identification of novel relevant genes to be further studied $^{(207)}$.
However, it is of major importance to identify interdependences between different classes of measurements (for example, zootechnical data $v$. histological $v$. gene expression data) ${ }^{(159)}$, and to obtain more additional information on possible modes of action by methods of bioinformatics (cluster analysis, comparison of thousands of expressed mRNA) ${ }^{(208)}$. For example, Hamard et al. ${ }^{(209)}$ investigated both the physiological disturbances and molecular events caused by an inadequate threonine supply to the ileum of piglets. Gene expression profiles were compared with responses of physiological origin. Most of the changes were consistent with an increase in metabolic activity including, for example, protein synthesis. The authors concluded that comparison of transcriptomic and physiological data may allow a better understanding of the functional implication of these genes as well as associated mechanism of regulation. However, to validate links between changes of gene expression and function, it is necessary to confirm biological interpretation of these results. Furthermore, it has to be kept in mind that data from gene expression studies may sometimes appear relatively unclear, because they are reflecting reactions of homogenised tissue segments, comprising different cell types. Thus, it would be necessary to link mRNA measurements with specific individual cell types (for example, by means of micro-dissection or immune histological techniques) ${ }^{(159)}$

In consequence, although a direct correlation between transcriptomic regulation and functional impact is not always easy to establish, studies exist suggesting fasting/ refeeding-induced gene regulations (for example, Mazurais et $\left.a l .{ }^{(35)}\right)$ to be consistent with alterations in the small intestine in piglets at weaning (for example, Marion et al. ${ }^{(210)}$; Boudry et $\left.a l .{ }^{(24)}\right)$. Thus, although given the limitation of gene expression studies, for example, need for comparisons between changes in gene expression with other, for example, morphological or zootechnical parameters, use of gene expression studies will help to gain deeper insight into the mechanism governing the physiological functions and their regulation in livestock species ${ }^{(207)}$. In that way, it will become possible to evaluate feeding regimens, compounds for non-pharmaceutical prevention of infectious enteral disease, and evaluation of pharmaceutical treatment of enteral diseases ${ }^{(36)}$.

\section{Implications for pig nutrition}

Dietary invention to prevent disease through feed supplementation has become a standard procedure in modern pig production systems. This requires, however, understanding of the ability to manipulate a multitude of nutrient-related interactions at the gene, protein and metabolic levels. Comparison of transcriptomic and physiological data may allow a better understanding of the functional implication of these genes as well as associated mechanisms of regulation ${ }^{(209)}$. Although direct 
correlation between transcriptomic regulation and functional impact is not always easy to establish, numerous studies have shown that nutrition-induced gene regulations observed are consistent with changes in intestinal structure and function.

By use of microarray technology, it has been shown that early weaning may lead to an increased expression of genes that promote oxidative stress and immune activation but decreased expression of genes related to nutrient utilisation and cell proliferation in the piglet's small intestine ${ }^{(7)}$. However, as weaning generally is associated with a reduced feed intake ${ }^{(21)}$, a clear distinction between effects of weaning and associated reduced feed intake on gene expression seems to be impossible. Also, weaning at early maturation stages frequently causes mucosal inflammation, which can be seen from an enhanced expression of pro-inflammatory cytokines. Thus, nutritional strategies are in favour that are capable of manipulating the secretion of pro-inflammatory cytokines ${ }^{(144)}$. Specific dietary fatty acids (for example, CLA) may have therapeutic potential, since they are able to influence the inflammatory response via specific transcription factors $^{(139)}$. Furthermore, specific feed ingredients, such as linseed, have been suggested as potential functional ingredients which may affect intestinal gene expression in young piglets after weaning ${ }^{(211)}$. Linseed contains a number of constituents, such as mucilage, gel-forming polysaccharides, structural carbohydrates and n-3 fatty acids, which could have functional properties in relation to maintaining and supporting gastrointestinal health in post-weaning piglets. For example, mRNA abundance of a lectin with anti-inflammatory properties which is expressed in the intestinal epithelium and involved in innate defence mechanisms was higher in linseed-fed pigs than in pigs fed the control diet. Stimulation or inhibition of such genes by feeding piglets a diet with specific functional constituents may be a promising way to improve intestinal health under stressful conditions such as weaning.

Also, providing a diet that best accommodates the profile of digestive enzymes and nutrient transporters present in the gut will result in improved utilisation of dietary nutrients, improved health and growth. For example, from a commercial livestock industry perspective, dietary protein is a costly nutrient, and even fractional improvements in its utilisation have the potential to reduce production costs as well as reduce the $\mathrm{N}$ excretion into the environment. Although dietary protein regulation of peptide transporter expression and activity has not been intensively studied in livestock, much of the work conducted in species used in biomedical research is broadly applicable, and provides a starting point for other studies aimed at determining the nutritional relevance of peptide transport $^{(39)}$. Further approaches may be based on the stimulation and promotion of rapid gastrointestinal development, thus supporting the animal to better cope with dietary changes associated with weaning. In this context, brush-border enzymes, such as lactase or maltase, are frequently used as cell markers of villus maturation $^{(212-214)}$. Accordingly, supplementation with specific dietary ingredients might offer the possibility to enhance proliferation and differentiation of epithelial cells and stimulate enzyme production in the upper GIT of weaned piglets.

Effects of specific dietary components may also be mediated rather indirectly via the metabolites produced from these components by the gastrointestinal microbiota, such as SCFA from carbohydrate fermentation or polyamines, which originate from protein fermentation. By changing the source and quantity of components available as fermentable substrates in the distal parts of the GIT, it may be possible to alter the amount and composition of microbial metabolites. For the SCFA, and particularly butyrate, it has been shown that they can influence the expression of various genes in the intestine, including, for example, cytokine expression. According to Pié et al. ${ }^{(74)}$, a diet enriched in fermentable carbohydrates can modulate the IL-6 mRNA content during the weaning period in piglets. Correlations between several pro-inflammatory cytokines and the endproducts of fermentation demonstrated that the regulation of cytokines is strongly linked to fermentation endproducts. As cytokines play a major role in the maintenance of gastrointestinal homeostasis, their regulation by nutritional factors may be an important consideration in the future for the development of new diet formulas for newly weaned piglets. Furthermore, dietary regulation of intestinal proglucagon expression via the ingestion of fermentable carbohydrates, associated with an increase in SCFA production, seems to be a promising approach in view of the physiological effects of intestinal PGDP. GLP-2, which may act as a physiological regulator of intestinal growth, has been suggested as a treatment for gastrointestinal diseases characterised by intestinal dysfunction. A stimulation of endogenous intestinal PGDP synthesis by the ingestion of specific dietary components could represent an alternative approach to exogenous GLP administration, and might be of considerable interest for therapeutic approaches.

However, it has to be kept in mind that changes in the intestine as they occur at weaning are often more a consequence of reduced feed intake, stress and inflammation than of dietary changes. This has been shown when investigating the impact of switching from milk-based to cerealbased diets on the morphology and function of the small intestine in piglets to isolate the influence of the diet from that of other factors, such as social or environmen$\mathrm{tal}^{(215)}$. With regard to mucosal integrity, the effect of diet composition seems not to be as important as the sequential effects of low feed intake during the first $4 \mathrm{~d}$ post-weaning. Accordingly, alterations of intestinal integrity were also observed in underfed piglets and piglets receiving TPN, when compared with their counterparts ad libitum or 
receiving enteral nutrition, independently of the weaning process $^{(26,56)}$. Thus, based on the present review, one major consequence would be stimulation of feed intake of piglets in the early post-weaning phase through various measures. This includes the use of specific feed ingredients that are well accepted by the animals. For example, dairy products, such as whey or skimmed milk powder have favourable effects on feed intake, and thus on health and growth performance ${ }^{(216)}$. Or, providing a weaner diet in liquid form enhances feed intake and thus health ${ }^{(217)}$. Also, supplementation of weaner diets with animal protein, for example, spray-dried plasma, may increase growth performance, most likely due to an increased feed intake, probably due to its high palatability, but also due to the anabolic activity of IGF-I present in spray-dried plasma $^{(218)}$.

As nutrient composition and availability seem to be more important in the reparative phase ${ }^{(219)}$, understanding how dietary factors can alter intestinal gene expression is an early step in the realisation of their therapeutic potential $^{(220)}$. The development of new strategies might involve stimulation of the immune response, reduction of the inflammatory response and improvement of nutrient digestion and transport. Improvement of the gut barrier function and mucosal repair by dietary factors might be other strategies to further improve health and animal performance. This can support intestinal health in times of disease or compromised feed intake such as at weaning. For such purposes, molecular nutritional science is of central interest. The response of mammalian organisms to changes in their nutritional environment may be detected at the mRNA and/or protein levels by different means, including expression arrays and proteome analysis, but also by use of transgenic approaches ${ }^{(221)}$. Such tools will allow identifying the mechanisms and pathways involved in the complex relationship between host factors and nutrition, but also the intestinal microflora.

\section{Conclusions}

In conclusion, dietary factors may have major impacts on intestinal gene expression, and deeper understanding of the underlying mechanisms and pathways is an early step in the realisation of their therapeutic potential. Stimulation or inhibition of genes by using specific functional constituents may be a convenient way to improve intestinal health under stressful conditions. For example, improvement of the gut barrier function and mucosal repair by dietary factors might be an interesting strategy to improve health and animal performance. In that way, intestinal health may be supported in times of disease or compromised feed intake such as at weaning. Furthermore, nutrients may be used by the intestinal microbiota resulting in the production of bacterial metabolites, which also may affect intestinal gene expression. Thus, modulation of the bacterial community by dietary ingredients, such as carbohydrate sources, can have sustainable effects on, for example, intestinal development and integrity. Since the microbiota affects a multitude of epithelial functions in the intestine due to specific bacterial-host interactions, the complex relationship between host, nutrition and intestinal microbiota has to be kept in mind when evaluating nutrition as a tool to influence gene expression.

\section{Acknowledgements}

This research received no specific grant from any funding agency in the public, commercial or not-for-profit sectors.

R. M., M. W. A. V. and E. B. were responsible for the conceptualisation and implementation of the manuscript. E. B. and B. U. M.-Z. wrote the manuscript. All authors reviewed the manuscript and approved it before submission. The authors wish to thank Ingrid Neff for assisting in preparing the manuscript.

There are no conflicts of interest.

\section{References}

1. Lallès JP, Boudry G, Favier C, et al. (2004) Gut function and dysfunction in young pigs: physiology. Anim Res $\mathbf{5 3}$ 301-316.

2. McCracken BA, Spurlock ME, Roos MA, et al. (1999) Weaning anorexia may contribute to local inflammation in the piglet small intestine. $J$ Nutr 129, 613-619.

3. Ihara T, Tsujikawa T, Fujiyama Y, et al. (2000) Regulation of PepT1 peptide transporter expression in the rat small intestine under malnourished conditions. Digestion 61, 59-67.

4. Ihara T, Tsujikawa T, Fujiyama Y, et al. (2000) Enhancement of brush border membrane peptidase activity in rat jejunum induced by starvation. Pflugers Arch 440, 75-83.

5. Ziegler TR, Almahfouz A, Pedrini MT, et al. (1995) A comparison of rat small intestinal insulin and insulin-like growth factor I receptors during fasting and refeeding. Endocrinology 136, 5148-5154.

6. Hoyt EC, Lund PK, Winesett DE, et al. (1996) Effects of fasting, refeeding, and intraluminal triglyceride on proglucagon expression in jejunum and ileum. Diabetes 45, 434-439.

7. Wang J, Chen L, Li P, et al. (2008) Gene expression is altered in piglet small intestine by weaning and dietary glutamine supplementation. J Nutr 138, 1025-1032.

8. Dauncey MJ, White P, Burton KA, et al. (2001) Nutritionhormone receptor-gene interactions: implications for development and disease. Proc Nutr Soc 60, 63-72.

9. Müller M \& Kersten S (2003) Nutrigenomics: goals and strategies. Nat Rev Genet 4, 315-322.

10. Mangelsdorf DJ, Thummel C, Beato M, et al. (1995) The nuclear receptor superfamily: the second decade. Cell $\mathbf{8 3}$, $835-839$.

11. Schoonjans K, Staels B \& Auwerx J (1996) Role of the peroxisome proliferator-activated receptor (PPAR) in mediating the effects of fibrates and fatty acids on gene expression. J Lipid Res 37, 907-925.

12. Kersten S, Desvergne B \& Wahli W (2000) Roles of PPARs in health and disease. Nature 405, 421-424.

13. Jiang C, Ting AT \& Seed B (1998) PPAR- $\gamma$ agonists inhibit production of monocyte inflammatory cytokines. Nature 391, 82-86. 
14. Marx N, Sukhova GK, Collins T, et al. (1999) PPAR $\alpha$ activators inhibit cytokine-induced vascular cell adhesion molecule-1 expression in human endothelial cells. Circulation 99, 3125-3131.

15. Pluske JR, Hampson DJ \& Williams IH (1997) Factors influencing the structure and function of the small intestine in the weaned pig: a review. Livest Prod Sci 51, 215-236.

16. Savage DC (1977) Microbial ecology of the gastrointestinal tract. Ann Rev Microbiol 31, 107-133.

17. Cousins RJ (1999) Nutritional regulation of gene expression. Am J Med 106, Suppl. 1, 20S-23S.

18. Davie JR (2003) Inhibition of histone deacetylase activity by butyrate. J Nutr 133, 2485S-2493S.

19. Williams BA, Verstegen MWA \& Tamminga S (2001) Fermentation in the large intestine of single-stomached animals and its relationship to animal health. Nutr Res Rev 14, 207-227.

20. Williams BA, Bosch MW, Boer H, et al. (2005) An in vitro batch culture method to assess potential fermentability of feed ingredients for monogastric diets. Anim Feed Sci Technol 123-124, 445-462.

21. Bruininx EMAM, Binnendijk GP, van der Peet-Schwering CMC, et al. (2002) Effect of creep feed consumption on individual feed intake characteristics and performance of group-housed weanling pigs. J Anim Sci 80, 1413-1418.

22. Hampson DJ (1994) Postweaning Escherichia coli diarrhoea in pigs. In Escherichia coli in Domestic Animals and Humans, 2nd ed., pp. 171-191 [CL Gyles, editor]. Wallingford: CAB International.

23. Spreeuwenberg MAM (2002) Diet composition and gut integrity in weaned piglets. PhD Thesis, Wageningen University.

24. Boudry G, Peron V, Le Huërou-Luron I, et al. (2004) Weaning induces both transient and long-lasting modifications of absorptive, secretory, and barrier properties of piglet intestine. J Nutr 134, 2256-2262.

25. Goldstein RM, Hebiguchi T, Luk GD, et al. (1985) The effects of total parenteral nutrition on gastrointestinal growth and development. J Pediatr Surg 20, 785-791.

26. Carey HV, Hayden UL \& Tucker KE (1994) Fasting alters basal and stimulated ion transport in piglet jejunum. $A m \mathrm{~J}$ Physiol Regul Integr Comp Physiol 267, R156-R163.

27. Pié S, Lallès JP, Blazy F, et al. (2004) Weaning is associated with an upregulation of expression of inflammatory cytokines in the intestine of piglets. J Nutr 134, 641-647.

28. McKay DM \& Baird AW (1999) Cytokine regulation of epithelial permeability and ion transport. Gut 44, 283-289.

29. Hillman K (2001) Bacteriological aspects of the use of antibiotics and their alternatives in the feed of non-ruminant animals. In Recent Advances in Animal Nutrition, pp. 107-134 [PC Garnsworthy and J Wiseman, editors]. Nottingham: Nottingham University Press.

30. Ewing WN \& Cole DJA (editors) (1994) The Living Gut. Dungannon: Context Publications.

31. Franklin MA, Mathew AG, Vickers JR, et al. (2002) Characterization of microbial populations and volatile fatty acid concentrations in the jejunum, ileum, and cecum of pigs weaned at 17 vs 24 days of age. J Anim Sci 80, 2904-2910.

32. Janczyk P, Pieper R, Smidt H, et al. (2007) Changes in the diversity of pig ileal lactobacilli around weaning determined by means of $16 \mathrm{~S}$ rRNA gene amplification and denaturing gradient gel electrophoresis. FEMS Microbiol Ecol 61, 132-140.

33. Konstantinov SR, Awati AA, Williams BA, et al. (2006) Postnatal development of the porcine microbiota composition and activities. Environ Microbiol 8, 1191-1199.

34. Hooper LV \& Gordon JI (2001) Commensal host-bacterial relationships in the gut. Science 292, 1115-1118.
35. Mazurais D, Romé V, Cahu A, et al. (2007) Fasting and refeeding impacts on piglet jejunal transcriptome during weaning period. Livest Sci 108, 13-16.

36. Niewold TA, Kerstens HHD, Van der Meulen J, et al. (2005) Development of a porcine small intestinal cDNA microarray: characterization and functional analysis of the response to enterotoxigenic E. coli. Vet Immunol Immunopathol 105, 317-329.

37. Castello A, Guma A, Sevilla L, et al. (1995) Regulation of GLUT5 gene expression in rat intestinal mucosa: regional distribution, circadian rhythm, perinatal development and effect of diabetes. Biochem J 309, 271-277.

38. Adibi SA (1997) The oligopeptide transporter (Pept-1) in human intestine: biology and function. Gastroenterology 113, 332-340.

39. Gilbert ER, Wong EA \& Webb KE Jr (2008) Board-invited review: Peptide absorption and utilization: implications for animal nutrition and health. J Anim Sci 86, 2135-2155.

40. Ogihara H, Suzuki T, Nagamachi Y, et al. (1999) Peptide transporter in the rat small intestine: ultrastructural localization and the effect of starvation and administration of amino acids. Histochem $J$ 31, 169-174.

41. Thamotharan M, Bawani SZ, Zhou X, et al. (1999) Functional and molecular expression of intestinal oligopeptide transporter (Pept-1) after a brief fast. Metabolism 48, 681-684.

42. Howard A, Goodlad RA, Walters JRF, et al. (2004) Increased expression of specific intestinal amino acid and peptide transporter mRNA in rats fed by TPN is reversed by GLP-2. J Nutr 134, 2957-2964.

43. Adibi SA (2003) Regulation of expression of the intestinal oligopeptide transporter (Pept-1) in health and disease. Am J Physiol Gastrointest Liver Physiol 285, G779-G788.

44. Barbot L, Windsor E, Rome S, et al. (2003) Intestinal peptide transporter PepT1 is over-expressed during acute cryptosporidiosis in suckling rats as a result of both malnutrition and experimental parasite infection. Parasitol Res 89, $364-370$.

45. Shimakura J, Terada T, Saito H, et al. (2006) Induction of intestinal peptide transporter 1 expression during fasting is mediated via peroxisome proliferator-activated receptor $\alpha$. Am J Physiol Gastrointest Liver Physiol 291, G851-G856

46. Francis GA, Fayard E, Picard F, et al. (2003) Nuclear receptors and the control of metabolism. Annu Rev Physiol $\mathbf{6 5}$, 261-311.

47. Corthésy-Theulaz I, Den Dunnen JT, Ferre P, et al. (2005) Nutrigenomics: the impact of biomics technology on nutrition research. Ann Nutr Metab 49, 355-365.

48. Dreyer C, Krey G, Keller H, et al. (1992) Control of the peroxisomal $\beta$-oxidation pathway by a novel family of nuclear hormone receptors. Cell 68, 879-887.

49. Tontonoz P, Hu E \& Spiegelman BM (1994) Stimulation of adipogenesis in fibroblasts by PPAR $\gamma 2$, a lipid-activated transcription factor. Cell 79, 1147-1156.

50. Kersten S, Seydoux J, Peters JM, et al. (1999) Peroxisome proliferator-activated receptor $\alpha$ mediates the adaptive response to fasting. J Clin Invest 103, 1489-1498.

51. Kaminsky LS \& Zhang QY (2003) The small intestine as a xenobiotic-metabolizing organ. Drug Metab Dispos 31, $1520-1525$.

52. Van den Bosch HM, Bünger M, de Groot PJ, et al. (2007) Gene expression of transporters and phase I/II metabolic enzymes in murine small intestine during fasting. BMC Genomics 8, 267.

53. Le Huërou-Luron I, Petersen YM, Hartmann B, et al. (2003) Exogenous GLP-2 has only marginal effects on weaning- 
induced intestinal adaptation in piglets. In Proceedings of the 9th International Symposium on Digestive Phyisology in Pigs, vol. 2, pp. 164-166 [RO Ball, editor]. Edmonton, AB: University of Alberta.

54. Marion J, Petersen YM, Romé V, et al. (2005) Early weaning stimulates intestinal brush border enzyme activities in piglets, mainly at the posttranscriptional level. J Pediatr Gastroenterol Nutr 41, 401-410.

55. Montagne L, Boudry G, Favier C, et al. (2007) Main intestinal markers associated with the changes in gut architecture and gut function in piglets after weaning. Br J Nutr 97, 45-57.

56. Park YK, Monaco MM \& Donovan SM (1998) Delivery of total parenteral nutrition (TPN) via umbilical catheterization: development of a piglet model to investigate therapies to improve gastrointestinal structure and enzyme activity during TPN. Biol Neonate 73, 295-305.

57. Matsunaga T, Shintani S \& Hara A (2006) Multiplicity of mammalian reductases for xenobiotic carbonyl compounds. Drug Metab Pharmacokinet 21, 1-18.

58. Wildhaber BE, Yang H, Spencer AU, et al. (2005) Lack of enteral nutrition-effects on the intestinal immune system. J Surg Res 123, 8-16.

59. Kiristioglu I \& Teitelbaum DH (1998) Alteration of the intestinal intraepithelial lymphocytes during total parenteral nutrition. J Surg Res 79, 91-96.

60. Yang H, Kiristioglu I, Fan Y, et al. (2002) Interferon- $\gamma$ expression by intraepithelial lymphocytes results in a loss of epithelial barrier function in a mouse model of total parenteral nutrition. Ann Surg 236, 226-234.

61. Alverdy JC, Aoys E \& Moss GS (1988) Total parenteral nutrition promotes bacterial translocation from the gut. Surgery 104, 185-190.

62. Fukatsu K, Kudsk KA, Zarzaur BL, et al. (2001) TPN decreases IL-4 and IL-10 mRNA expression in lipopolysaccharide stimulated intestinal lamina propria cells but glutamine supplementation preserves the expression. Shock $\mathbf{1 5}$, 318-322.

63. Kramer DR, Sutherland RM, Bao S, et al. (1995) Cytokine mediated effects in mucosal immunity. Immunol Cell Biol 73, 389-396.

64. Abbas AK \& Lichtman AH (editors) (2001) Basic Immunology: Functions and Disorders of the Immune System. Philadelphia, PA: W.B. Saunders Company.

65. Chipman DM \& Sharon N (1969) Mechanism of lysozyme action. Science 165, 454-465.

66. Wu G, Fang YZ, Yang S, et al. (2004) Glutathione metabolism and its implications for health. J Nutr 134, 489-492.

67. Aw TT (1999) Molecular and cellular responses to oxidative stress and changes in oxidation-reduction imbalance in the intestine. Am J Clin Nutr 70, 557-565.

68. Young D, Fan MZ \& Mine Y (2010) Egg yolk peptides upregulate glutathione synthesis and antioxidant enzyme activities in a porcine model of intestinal oxidative stress. J Agric Food Chem 58, 7624-7633.

69. Papparella A, DeLuca FG, Oyer CE, et al. (1997) Ischemiareperfusion injury in the intestines of newborn pigs. Pediatr Res 42, 180-188.

70. Haase E, Bigam DL, Nakonechny QB, et al. (2004) Resuscitation with $100 \%$ oxygen causes intestinal glutathione oxidation and reoxygenation injury in asphyxiated newborn piglets. Ann Surg 240, 364-373.

71. Mengheri E, Ciapponi L, Vignolini F, et al. (1996) Cytokine gene expression in intestine of rat during the postnatal developmental period: increased IL-1 expression at weaning. Life Sci 59, 1227-1236.
72. Schaeffer C, Diab-Assef M, Plateroti M, et al. (2000) Cytokine gene expression during postnatal small intestinal development: regulation by glucocorticoids. Gut 47, 192-198.

73. Kandil HM, Berschneider HM \& Argenzio RA (1994) Tumour necrosis factor $\alpha$ changes porcine intestinal ion transport through a paracrine mechanism involving prostaglandins. Gut 35, 934-940.

74. Pié S, Awati A, Vida S, et al. (2007) Effects of added fermentable carbohydrates in the diet on intestinal proinflammatory cytokine-specific mRNA content in weaning piglets. J Anim Sci 85, 673-683.

75. Ganessunker D, Gaskins HR, Zuckermann FA, et al. (1999) Total parenteral nutrition alters molecular and cellular indices of intestinal inflammation in neonatal piglets. J Parenter Enteral Nutr 23, 337-344.

76. Zijlstra RT, McCracken BA, Odle J, et al. (1999) Malnutrition modifies pig small intestinal inflammatory responses to rotavirus. J Nutr 129, 838-843.

77. Winesett DE, Ulshen MH, Hoyt EC, et al. (1995) Regulation and localization of the insulin-like growth factor system in small bowel during altered nutrient status. Am J Physiol Gastrointest Liver Physiol 268, G631-G640.

78. Dahly EM, Guo Z \& Ney DM (2002) Alterations in enterocyte proliferation and apoptosis accompany TPN-induced mucosal hypoplasia and IGF-I-induced hyperplasia in rats. J Nutr 132, 2010-2014.

79. Straus DS (1994) Nutritional regulation of hormones and growth factors that control mammalian growth. FASEB $J$ 8, 6-12.

80. Laburthe M, Rouyer-Fessard C \& Gammeltoft S (1988) Receptors for insulin-like growth factors I and II in rat gastrointestinal epithelium. Am J Physiol Gastrointest Liver Physiol 254, G457-G462.

81. LeRoith D, Werner H, Beitner-Johnson D, et al. (1995) Molecular and cellular aspects of the insulin-like growth factor I receptor. Endocr Rev 16, 143-163.

82. Hardouin S, Hossenlopp P, Segovia B, et al. (1987) Heterogeneity of insulin-like growth factor binding proteins and relationships between structure and affinity. 1. Circulating forms in man. Eur J Biochem 170, 121-132.

83. Cohick WS \& Clemmons DR (1993) The insulin-like growth factors. Annu Rev Physiol 55, 131-153.

84. Simmen FA, Badinga L, Green ML, et al. (1998) The porcine insulin-like growth factor system: at the interface of nutrition, growth and reproduction. J Nutr 128, 315S-320S.

85. Rubin JS, Osada H, Finch PW, et al. (1989) Purification and characterization of a newly identified growth factor specific for epithelial cells. Proc Natl Acad Sci U S A 86, 802-806.

86. Housley RM, Morris CF, Boyle W, et al. (1994) Keratinocyte growth factor induces proliferation of hepatocytes and epithelial cells throughout the rat gastrointestinal tract. J Clin Invest 94, 1764-1777.

87. Estívariz CF, Gu LH, Scully S, et al. (2000) Regulation of keratinocyte growth factor (KGF) and KGF receptor mRNAs by nutrient intake and KGF administration in rat intestine. Dig Dis Sci 45, 736-743.

88. Shoubridge CA, Steeb CB \& Read LC (2001) IGFBP mRNA expression in small intestine of rat during postnatal development. Am J Physiol Gastrointest Liver Physiol 281, G1378-G1384.

89. Tang M, Van Kessel AG \& Laarveld B (2002) Effects of weaning and rearing environment on intestinal gene expression of IGF-I, IGFBP (1-6), and the IGF receptor and on specific binding of IGF-I to mucosal membranes in the pig. Gen Comp Endocrinol 128, 205-213.

90. Brubaker PL \& Drucker DJ (2004) Minireview: Glucagonlike peptides regulate cell proliferation and apoptosis 
in the pancreas, gut, and central nervous system. Endocrinology 145, 2653-2659.

91. Holst JJ (1997) Enteroglucagon. Annu Rev Physiol 59, 257-271.

92. Shin ED, Estall JL, Izzo A, et al. (2005) Mucosal adaptation to enteral nutrients is dependent on the physiologic actions of glucagon-like peptide-2 in mice. Gastroenterology 128, $1340-1353$.

93. Burrin DG, Stoll B \& Guan X (2003) Glucagon-like peptide 2 function in domestic animals. Domest Anim Endocrinol 24, 103-122.

94. Nian M, Gu J, Irwin DM, et al. (2002) Human glucagon gene promoter sequences regulating tissue-specific versus nutrient-regulated gene expression. Am J Physiol Regul Integr Comp Physiol 282, R173-R183.

95. Nelson DW, Murali SG, Liu X, et al. (2008) Insulin-like growth factor I and glucagon-like peptide-2 responses to fasting followed by controlled or ad libitum refeeding in rats. Am J Physiol Regul Integr Comp Physiol 294, R1175-R1184.

96. Petersen YM, Hartmann B, Holst JJ, et al. (2003) Introduction of enteral food increases plasma GLP-2 and decreases GLP-2 receptor mRNA abundance during pig development. J Nutr 133, 1781-1786.

97. Macfarlane GT \& Cummings JH (1991) The colonic flora, fermentation, and large bowel digestive function. In The Large Intestine - Physiology, Pathophysiology and Disease, pp. 51-92 [SF Phillips, JH Pemberton and RG Shorter, editors]. New York: Raven Press.

98. Li L, Rao JN, Guo X, et al. (2001) Polyamine depletion stabilizes p53 resulting in inhibition of normal intestinal epithelial cell proliferation. Am J Physiol Cell Physiol 281, C941-C953.

99. Liu L, Li L, Rao JN, et al. (2005) Polyamine-modulated expression of $c-m y c$ plays a critical role in stimulation of normal intestinal epithelial cell proliferation. Am J Physiol Cell Physiol 288, C89-C99.

100. Zhang HM, Rao JN, Guo X, et al. (2004) Akt kinase activation blocks apoptosis in intestinal epithelial cells by inhibiting caspase-3 after polyamine depletion. $J$ Biol Chem 279, 22539-22547.

101. McCormack SA \& Johnson LR (1991) Role of polyamines in gastrointestinal mucosal growth. Am J Physiol Gastrointest Liver Physiol 260, G795-G806.

102. Wang JY \& Polyamines RN (2007) A stability in regulation of intestinal mucosal growth. Amino Acids 33, 241-252.

103. Erickson RH, Gum JR Jr, Lindstrom MM, et al. (1995) Regional expression and dietary regulation of rat small intestinal peptide and amino acid transporter mRNAs. Biochem Biophys Res Commun 216, 249-257.

104. Shiraga T, Miyamoto KI, Tanaka H, et al. (1999) Cellular and molecular mechanisms of dietary regulation on rat intestinal $\mathrm{H}^{+}$/peptide transporter PepT1. Gastroenterology $\mathbf{1 1 6}$, 354-362.

105. Thamotharan M, Bawani SZ, Zhou X, et al. (1998) Mechanism of dipeptide stimulation of its own transport in a human intestinal cell line. Proc Assoc Am Physicians 110, 361-368.

106. Walker D, Thwaites DT, Simmons NL, et al. (1998) Substrate upregulation of the human small intestinal peptide transporter, hPepT1. J Physiol 507, 697-706.

107. Chen H, Pan YX, Wong EA, et al. (2005) Dietary protein level and stage of development affect expression of an intestinal peptide transporter (cPepT1) in chickens. $J$ Nutr 135, 193-198.

108. Ferraris RP, Diamond J \& Kwan WW (1988) Dietary regulation of intestinal transport of the dipeptide carnosine. Am J Physiol Gastrointest Liver Physiol 255, G143-G150.
109. Xiao X, Wong EA \& Webb KE (2004) Developmental regulation of fructose and amino acid transporter gene expression in the small intestine of pigs. J Dairy Sci $\mathbf{8 7}$, Suppl. 1, 25.

110. Shen H, Smith DE \& Brosius FC III (2001) Developmental expression of PepT1 and PepT2 in rat small intestine, colon, and kidney. Pediatr Res 49, 789-795.

111. Wang W, Shi C, Zhang J, et al. (2009) Molecular cloning, distribution and ontogenetic expression of the oligopeptide transporter PepT1 mRNA in Tibetan suckling piglets. Amino Acids 37, 593-601.

112. Wu G, Meier SA \& Knabe DA (1996) Dietary glutamine supplementation prevents jejunal atrophy in weaned pigs. J Nutr 126, 2578-2584.

113. Steyaert H, Tonon MC, Tong Y, et al. (1991) Distribution and characterization of endogenous benzodiazepine receptor ligand (endozepine)-like peptides in the rat gastrointestinal tract. Endocrinology 129, 2101-2109.

114. Pusch W, Jähner D, Spiess AN, et al. (1999) Rat endozepinelike peptide (ELP): cDNA cloning, genomic organization and tissue-specific expression. Gene 235, 51-57.

115. Morimoto M, Morimoto M, Zhao A, et al. (2006) Functional importance of regional differences in localized gene expression of receptors for IL-13 in murine gut. J Immunol 176, 491-495.

116. O'Loughlin EV, Scott RB \& Gall DG (1991) Pathophysiology of infectious diarrhea: changes in intestinal structure and function. J Pediatr Gastroenterol Nutr 12, 5-20.

117. Agerberth B, Boman A, Andersson M, et al. (1993) Isolation of three antibacterial peptides from pig intestine: gastric inhibitory polypeptide(7-42), diazepam-binding inhibitor(32-86) and a novel factor, peptide 3910. Eur J Biochem 216, 623-629.

118. Zarlenga DS, Dawson H, Kringel H, et al. (2004) Molecular cloning of the swine IL- 4 receptor $\alpha$ and IL- 13 receptor 1 chains: effects of experimental Toxoplasma gondii, Ascaris suum and Trichuris suis infections on tissue mRNA levels. Vet Immunol Immunopathol 101, 223-234.

119. Lallès JP, Bosi P, Smidt H, et al. (2007) Weaning - a challenge to gut physiologists. Livest Sci 108, 82-93.

120. Anggard E (1994) Nitric oxide: mediator, murderer, and medicine. Lancet 343, 1199-1206.

121. Sukhotnik I, Helou H, Mogilner J, et al. (2005) Oral arginine improves intestinal recovery following ischemia-reperfusion injury in rat. Pediatr Surg Int 21, 191-196.

122. Fu TL, Zhang WT, Zhang L, et al. (2005) L-Arginine administration ameliorates serum and pulmonary cytokine response after gut ischemia-reperfusion in immature rats. World J Gastroenterol 11, 1070-1072.

123. Liu Y, Huang J, Hou Y, et al. (2008) Dietary arginine supplementation alleviates intestinal mucosal disruption induced by Escherichia coli lipopolysaccharide in weaned pigs. Br J Nutr 100, 552-560.

124. Nakajima A, Wada K, Miki H, et al. (2001) Endogenous PPAR $\gamma$ mediates anti-inflammatory activity in murine ischemia-reperfusion injury. Gastroenterology 120, 460-469.

125. Sato N, Kozar RA, Zou L, et al. (2005) Peroxisome proliferator-activated receptor $\gamma$ mediates protection against cyclooxygenase-2-induced gut dysfunction in a rodent model of mesenteric ischemia/reperfusion. Shock 24, 462-469.

126. Moraes LA, Piqueras L \& Bishop-Bailey D (2006) Peroxisome proliferator-activated receptors and inflammation. Pharmacol Ther 110, 371-385.

127. Calkins CM, Bensard DD, Heimbach JK, et al. (2001) L-Arginine attenuates lipopolysaccharide-induced lung chemokine production. Am J Physiol Lung Cell Mol Physiol 280, L400-L408. 
128. Desreumaux P, Dubuquoy L, Nutten S, et al. (2001) Attenuation of colon inflammation through activators of the retinoid $\mathrm{X}$ receptor (RXR)/peroxisome proliferator-activated receptor $\gamma$ (PPAR $\gamma)$ heterodimer: a basis for new therapeutic strategies. J Exp Med 193, 827-838.

129. Yasutake H, Goda T \& Takase S (1995) Dietary regulation of sucrase-isomaltase gene expression in rat jejunum. Biochim Biophys Acta 1243, 270-276.

130. Hediger MA, Coady MJ, Ikeda TS, et al. (1987) Expression cloning and CDNA sequencing of the $\mathrm{Na}^{+} /$glucose co-transporter. Nature 330, 379-381.

131. Black DD, Rohwer-Nutter PL \& Davidson NO (1990) Intestinal apolipoprotein A-IV gene expression in the piglet. J Lipid Res 31, 497-505.

132. Black DD, Wang H, Hunter F, et al. (1996) Intestinal expression of apolipoprotein A-IV and C-III is coordinately regulated by dietary lipid in newborn swine. Biochem Biophys Res Commun 221, 619-624.

133. Stan S, Delvin E, Lambert M, et al. (2003) Apo A-IV: an update on regulation and physiologic functions. Biochim Biophys Acta 1631, 177-187.

134. Lu S, Yao Y, Meng S, et al. (2002) Overexpression of apolipoprotein A-IV enhances lipid transport in newborn swine intestinal epithelial cells. J Biol Chem 277, 31929-31937.

135. Mochizuki K, Mochizuki H, Kawai H, et al. (2007) Possible role of fatty acids in milk as the regulator of the expression of cytosolic binding proteins for fatty acids and vitamin A through PPAR $\alpha$ in developing rats. J Nutr Sci Vitaminol 53, 515-521.

136. Kono H, Fujii H, Asakawa M, et al. (2004) Medium-chain triglycerides enhance secretory IgA expression in rat intestine after administration of endotoxin. Am J Physiol Gastrointest Liver Physiol 286, G1081-G1089.

137. Mayer L (1997) The role of the epithelium in mucosal immunity. Res Immunol 148, 498-504.

138. Hontecillas R, Wannemeulher MJ, Zimmerman DR, et al. (2002) Nutritional regulation of porcine bacterial-induced colitis by conjugated linoleic acid. J Nutr 132, 2019-2027.

139. Bassaganya-Riera J, Reynolds K, Martino-Catt S, et al. (2004) Activation of PPAR $\gamma$ and $\delta$ by conjugated linoleic acid mediates protection from experimental inflammatory bowel disease. Gastroenterology 127, 777-791.

140. Delerive P, Fruchart J-C \& Staels B (2001) Peroxisome proliferator-activated receptors in inflammation control. J Endocrinol 169, 453-459.

141. Levy BD, Clish CB, Schmidt B, et al. (2001) Lipid mediator class switching during acute inflammation: signals in resolution. Nat Immunol 2, 612-619.

142. Ricote M, Li AC, Willson TM, et al. (1998) The peroxisome proliferator-activated receptor- $\gamma$ is a negative regulator of macrophage activation. Nature 391, 79-82.

143. Bassaganya-Riera J \& Hontecillas R (2006) CLA and n-3 PUFA differentially modulate clinical activity and colonic PPAR-responsive gene expression in a pig model of experimental IBD. Clin Nutr 25, 454-465.

144. Changhua L, Jindong Y, Defa L, et al. (2005) Conjugated linoleic acid attenuates the production and gene expression of proinflammatory cytokines in weaned pigs challenged with lipopolysaccharide. J Nutr 135, 239-244.

145. Tanaka T, Kishi K, Igawa M, et al. (1998) Dietary carbohydrates enhance lactase/phlorizin hydrolase gene expression at a transcription level in rat jejunum. Biochem J 331, 225-230.

146. Kishi K, Tanaka T, Igawa M, et al. (1999) Sucrase-isomaltase and hexose transporter gene expressions are coordinately enhanced by dietary fructose in rat jejunum. $J$ Nutr 129, 953-956.
147. Goda T, Yasutake H, Suzuki Y, et al. (1995) Diet-induced changes in gene expression of lactase in rat jejunum. Am J Physiol Gastrointest Liver Physiol 268, G1066-G1073.

148. Goda $\mathrm{T}$ (2000) Regulation of the expression of carbohydrate digestion/absorption-related genes. Br J Nutr 84, S245-S248.

149. Cui XL, Soteropoulos P, Tolias P, et al. (2004) Fructoseresponsive genes in the small intestine of neonatal rats. Physiol Genomics 18, 206-217.

150. Jiang L, David ES, et al. (2001) GLUT-5 expression in neonatal rats: crypt-villus location and age-dependent regulation. Am J Physiol Gastrointest Liver Physiol 281, G666-G674.

151. Douard V, Cui X-L, Soteropoulos P, et al. (2008) Dexamethasone sensitizes the neonatal intestine to fructose induction of intestinal fructose transporter (Slc2A5) function. Endocrinology 149, 409-423.

152. Lesage J, Blondeau B, Grino M, et al. (2001) Maternal under-nutrition during late gestation induces fetal overexposure to glucocorticoids and intrauterine growth retardation, and disturbs the hypothalamo-pituitary adrenal axis in the newborn rat. Endocrinology 142, 1692-1702.

153. Tako E, Glahn RP, Welch RM, et al. (2008) Dietary inulin affects the expression of intestinal enterocyte iron transporters, receptors and storage protein and alters the microbiota in the pig intestine. BrJ Nutr 99, 472-480.

154. Loh G, Eberhard M, Brunner RM, et al. (2006) Inulin alters the intestinal microbiota and short-chain fatty acid concentrations in growing pigs regardless of their basal diet. J Nutr 136, 1198-1202.

155. Mikkelsen LL \& Jensen BB (2004) Effect of fructo-oligosaccharides and transgalacto-oligosaccharides on microbial populations and microbial activity in the gastrointestinal tract of piglets post-weaning. Anim Feed Sci Technol 117, 107-119.

156. Kanauchi O, Serizawa I, Araki Y, et al. (2003) Germinated barley foodstuff, a prebiotic product, ameliorates inflammation of colitis through modulation of the enteric environment. J Gastroenterol 38, 134-141.

157. Yin YL, Tang ZR, Sun ZH, et al. (2008) Effect of galactomannan-oligosaccharides or chitosan supplementation on cytoimmunity and humoral immunity in early-weaned piglets. Asian-Australas J Anim Sci 21, 723-731.

158. Yang F, Wang J, Li X, et al. (2007) 2-DE and MS analysis of interactions beween Lactobacillus fermentum 15007 and intestinal epithelial cells. Electrophoresis 28, 4330-4339.

159. Schedle K, Pfaffl MW, Plitzner C, et al. (2008) Effect of insoluble fibre on intestinal morphology and mRNA expression pattern of inflammatory, cell cycle and growth marker genes in a piglet model. Arch Anim Nutr 62 , 427-438.

160. Massimino SP, McBurney MI, Field CJ, et al. (1998) Fermentable dietary fiber increases GLP-1 secretion and improves glucose homeostasis despite increased intestinal glucose transport capacity in healthy dogs. J Nutr 128, 1786-1793.

161. Cani PD, Dewever C \& Delzenne NM (2004) Inulin-type fructans modulate gastrointestinal peptides involved in appetite regulation (glucagon-like peptide-1 and ghrelin) in rats. Br J Nutr 92, 521-526.

162. Reimer RA \& McBurney MI (1996) Dietary fiber modulates intestinal proglucagon messenger ribonucleic acid and postprandial secretion of glucagon-like peptide-1 and insulin in rats. Endocrinology 137, 3948-3956.

163. Tappenden KA \& McBurney MI (1998) Systemic short-chain fatty acids rapidly alter gastrointestinal structure, function, and expression of early response genes. Dig Dis Sci $\mathbf{4 3}$, 1526-1536. 
164. Tappenden KA, Thomson ABR, Wild GE, et al. (1996) Short-chain fatty acids increase proglucagon and ornithine decarboxylase messenger RNAs after intestinal resection in rats. J Parenter Enteral Nutr 20, 357-362.

165. Tappenden KA, Drozdowski LA, Thomson AB, et al. (1998) Short-chain fatty acid-supplemented total parenteral nutrition alters intestinal structure, glucose transporter 2 (GLUT2) mRNA and protein, and proglucagon mRNA abundance in normal rats. Am J Clin Nutr 68, 118-125.

166. Drozdowski LA, Dixon WT, McBurney MI, et al. (2002) Shortchain fatty acids and total parenteral nutrition affect intestinal gene expression. J Parenter Enteral Nutr 26, 145-150.

167. Thulesen J, Hartmann B, Nielsen C, et al. (1999) Diabetic intestinal growth adaptation and glucagon-like peptide 2 in the rat: effects of dietary fibre. Gut 45, 672-678.

168. Thulesen J (2004) Glucagon-like peptide 2 (GLP-2), an intestinotrophic mediator. Curr Protein Pept Sci 5, 51-65.

169. Cani PD, Neyrinck AM, Maton N, et al. (2005) Oligofructose promotes satiety in rats fed a high-fat diet: involvement of glucagon-like peptide-1. Obes Res 13, 1000-1007.

170. Delzenne NM, Cani PD, Daubioul C, et al. (2005) Impact of inulin and oligofructose on gastrointestinal peptides. $\mathrm{Br} \mathrm{J}$ Nutr 93, Suppl. 1, S157-S161.

171. Leser TD \& Mølbak L (2009) Better living through microbial action: the benefits of the mammalian gastrointestinal microbiota on the host. Environ Microbiol 11, 2194-2206.

172. Castillo M, Skene G, Roca M, et al. (2007) Application of $16 \mathrm{~S}$ rRNA gene-targetted fluorescence in situ hybridization and restriction fragment length polymorphism to study porcine microbiota along the gastrointestinal tract in response to different sources of dietary fibre. FEMS Microbiol Ecol 59, $138-146$.

173. Kozakova H, Kolinska J, Lojda Z, et al. (2006) Effect of bacterial monoassociation on brush-border enzyme activities in ex-germ-free piglets: comparison of commensal and pathogenic Escherichia coli strains. Microbes Infect $\mathbf{8}$, $2629-2639$.

174. Siggers RH, Shirkey TW, Drew MD, et al. (2008) Cloning of porcine proglucagon and effect of commensal bacteria on relative gene expression in the intestine of gnotobiotic pigs. Can J Anim Sci 88, 429-438.

175. Hooper LV, Wong MH, Thelin A, et al. (2001) Molecular analysis of commensal host-microbial relationships in the intestine. Science 291, 881-884.

176. Nerstedt A, Nilsson EC, Ohlson K, et al. (2007) Administration of Lactobacillus evokes coordinated changes in the intestinal expression profile of genes regulating energy homeostasis and immune phenotype in mice. Br J Nutr 97, 1117-1127.

177. Burrin DG, Stoll B, Jiang R, et al. (2000) GLP-2 stimulates intestinal growth in premature TPN-fed pigs by suppressing proteolysis and apoptosis. Am J Physiol Gastrointest Liver Physiol 279, G1249-G1256.

178. Willing BP \& Van Kessel AG (2007) Enterocyte proliferation and apoptosis in the caudal small intestine is influenced by the composition of colonizing commensal bacteria in the neonatal gnotobiotic pig. J Anim Sci 85, 3256-3266.

179. Mutch DM, Simmering R, Donnicola D, et al. (2004) Impact of commensal microbiota on murine gastrointestinal tract gene ontologies. Physiol Genomics 19, 22-31.

180. Shirkey TW, Siggers RH, Goldade BG, et al. (2006) Effects of commensal bacteria on intestinal morphology and expression of proinflammatory cytokines in the gnotobiotic pig. Exp Biol Med 231, 1333-1345.

181. Chowdhury SR, King DE, Willing BP, et al. (2007) Transcriptome profiling of the small intestinal epithelium in germfree versus conventional piglets. BMC Genomics 8, 215-230.
182. Kruh J (1982) Effects of sodium butyrate, a new pharmacological agent, on cells in culture. Mol Cell Biochem $\mathbf{4 2}$, $65-82$.

183. McCaffrey PG, Newsome DA, Fibach E, et al. (1997) Induction of $\gamma$-globin by histone deacetylase inhibitors. Blood $\mathbf{9 0}$, 2075-2083.

184. Fusunyan RD, Quinn JJ, Fujimoto M, et al. (1999) Butyrate switches the pattern of chemokine secretion by intestinal epithelial cells through histone acetylation. $\mathrm{Mol} \mathrm{Med} \mathbf{5}$, 631-640

185. Harig JM, Soergel KH, Komorowski RA, et al. (1989) Treatment of diversion colitis with short-chain-fatty acid irrigation. $N$ Engl J Med 320, 23-28.

186. Izzo RS, Witkon K, Chen AI, et al. (1993) Neutrophil-activating peptide (interleukin-8) in colonic mucosa from patients with Crohn's disease. Scand J Gastroenterol 28, 296-300.

187. MacDermott RP, Sanderson IR \& Reinecker HC (1998) The central role of chemokines (chemotactic cytokines) in the immunopathogenesis of ulcerative colitis and Crohn's disease. Inflamm Bowel Dis 4, 54-67.

188. Gibson P \& Rosella O (1995) Interleukin 8 secretion by colonic crypt cells in vitro: response to injury suppressed by butyrate and enhanced in inflammatory bowel disease. Gut 37, 536-543.

189. Segain JP, Raingeard de la Bletiere D, Bourreille A, et al. (2000) Butyrate inhibits inflammatory responses through NFкB inhibition: implications for Crohn's disease. Gut $\mathbf{4 7}$, 397-403

190. Zapolska-Downar D, Siennicka A, Kaczmarczyk M, et al. (2004) Butyrate inhibits cytokine-induced VCAM-1 and ICAM-1 expression in cultured endothelial cells: the role of NF-кB and PPAR $\alpha$. J Nutr Biochem 15, 220-228.

191. Baldwin AS Jr (1996) The NF-кB and ІкB proteins: new discoveries and insights. Annu Rev Immunol 14, 649-683.

192. Inan MS, Rasoulpour RJ, Yin L, et al. (2000) The luminal short-chain fatty acid butyrate modulates NF- $\mathrm{B}$ activity in a human colonic epithelial cell line. Gastroenterology $\mathbf{1 1 8}$, $724-734$

193. Weber TE \& Kerr BJ (2008) Effect of sodium butyrate on growth performance and response to lipopolysaccaride in weanling pigs. J Anim Sci 86, 442-450.

194. Milo LA, Reardon KA \& Tappenden KA (2002) Effects of short-chain fatty acid-supplemented total parenteral nutrition on intestinal pro-inflammatory cytokine abundance. Dig Dis Sci 47, 2049-2055.

195. Zhang LT, Yao YM, Lu JQ, et al. (2007) Sodium butyrate prevents lethality of severe sepsis in rats. Shock 27, 672-677.

196. Leoni F, Fossati G, Lewis EC, et al. (2005) The histone deacetylase inhibitor ITF2357 reduces production of proinflammatory cytokines in vitro and systemic inflammation in vivo. Mol Med 11, 1-15.

197. Nishimura A, Fujimoto M, Oguchi S, et al. (1998) Shortchain fatty acids regulate IGF-binding protein secretion by intestinal epithelial cells. Am J Physiol Endocrinol Metab 275, E55-E63.

198. Lund PK \& Zimmermann EM (1996) Insulin-like growth factors and inflammatory bowel disease. Baillieres Clin Gastroenterol 10, 83-96.

199. Wild GE, Searles LE, Koski KG, et al. (2007) Oral polyamine administration modifies the ontogeny of hexose transporter gene expression in the postnatal rat intestine. Am J Physiol Gastrointest Liver Physiol 293, G453-G460.

200. Blachier F, Mariotti F, Huneau JF, et al. (2007) Effects of amino acid-derived luminal metabolites on the colonic epithelium and physiopathological consequences. Amino Acids 33, 547-562. 
201. Motyl T, Ploszaj T, Wojtasik A, et al. (1995) Polyamines in cow's and sow's milk. Comp Biochem Physiol B Biochem Mol Biol 111, 427-433.

202. Schultz SG \& Hudson RL (1991) Biology of sodium-absorbing epithelial cells: dawning of a new era. In Handbook of Physiology. The Gastrointestinal System. Intestinal Absorption and Secretion, vol. IV, 2nd ed., pp. 45-81 [M Field and RA Frizzell, editors]. Bethesda, MD: American Physiological Society.

203. Luk GD, Marton LJ \& Baylin SB (1980) Ornithine decarboxylase is important in intestinal mucosal maturation and recovery from injury in rats. Science 210, 195-198.

204. Chen J, Rao JN, Zou T, et al. (2007) Polyamines are required for expression of Toll-like receptor 2 modulating intestinal epithelial barrier integrity. Am J Physiol Gastrointest Liver Physiol 293, G568-G576.

205. Abreu MT, Fukata M \& Arditi M (2005) TLR signaling in the gut in health and disease. J Immunol 174, 4453-4460.

206. Janeway CA Jr \& Medzhitov R (2002) Innate immune recognition. Annu Rev Immunol 20, 197-216.

207. Cassar-Malek I, Picard B, Bernard C, et al. (2008) Application of gene expression studies in livestock production systems: a European perspective. Aust J Exp Agric 48, $701-710$.

208. D'Haeseleer P (2005) How does gene expression clustering work? Nat Biotechnol 23, 1499-1501.

209. Hamard A, Mazurais D, Boudry G, et al. (2007) Physiological aspects and ileal gene expression profile of earlyweaned piglets fed a low threonine diet. Livest Sci 108, $17-19$.

210. Marion J, Biernat M, Thomas F, et al. (2002) Small intestine growth and morphometry in piglets weaned at 7 days of age, effect of level of energy intake. Reprod Nutr Dev $\mathbf{4 2}$, 339-354.

211. Jansman AJM, Niewold TA \& Hulst MM (2007) Inclusion of linseed and linseed expeller meal in piglet diets affects intestinal gene expression profiles. Livest Sci 108, 23-25.

212. James PS, Smith MW, Tivey DR, et al. (1987) Epidermal growth factor selectively increases maltase and sucrase activities in neonatal piglet intestine. J Physiol 393, 583-594.
213. Collins J, Starkey WG, Wallis TS, et al. (1988) Intestinal enzyme profiles in normal and rotavirus-infected mice. J Pediatr Gastroenterol Nutr 7, 264-272.

214. Lifschitz CH, Smith EO \& Garza C (1983) Delayed complete functional lactase sufficiency in breast-fed infants. J Pediatr Gastroenterol Nutr 2, 478-482.

215. Boudry G, Lallès JP, Malbert CH, et al. (2002) Diet-related adaptation of the small intestine at weaning in pigs is functional rather than structural. J Pediatr Gastroenterol Nutr 34, 180-187.

216. Thacker PA (1999) Nutritional requirements of early weaned pigs: a review. Pig News Info 20, 13N-24N.

217. Brooks PH, Moran CA, Beal JD, et al. (2001) Liquid feeding for the young piglet. In The Weaner Pig: Nutrition and Management, pp. 153-178 [MA Varley and J Wiseman, editors]. Wallingford: CAB International.

218. Van Dijk AJ, Everts H, Nabuurs NJA, et al. (2001) Growth performance of weaned pigs fed spray-dried animal plasma: a review. Livest Prod Sci 68, 263-274.

219. Spreeuwenberg MAM, Verdonk JMAJ, Gaskins HR, et al. (2001) Small intestine epithelial barrier function is compromised in pigs with low feed intake at weaning. J Nutr $\mathbf{1 3 1}$, $1520-1527$

220. Sanderson IR \& Naik S (2000) Dietary regulation of intestinal gene expression. Annu Rev Nutr 20, 311-338.

221. Stierum R, Burgemeister R, van Helvoort A, et al. (2001) Functional food ingredients against colorectal cancer. An example project integrating functional genomics, nutrition and health. Nutr Metab Cardiovasc Dis 11, Suppl., 94-98.

222. Reimer RA, Thomson ABR, Rajotte RV, et al. (1997) A physiological level of rhubarb fiber increases proglucagon gene expression and modulates intestinal glucose uptake in rats. J Nutr 127, 1923-1928.

223. Ogawa H, Rafiee P, Fisher PJ, et al. (2003) Butyrate modulates gene and protein expression in human intestinal endothelial cells. Biochem Biophys Res Commun 309, 512-519.

224. Fusunyan RD, Quinn JJ, Ohno Y, et al. (1998) Butyrate enhances interleukin (IL)-8 secretion by intestinal epithelial cells in response to IL-1[beta] and lipopolysaccharide 1. Pediatr Res 43, 84-90. 